

\title{
أساليب المعاملة الوالدية ودور ها في تعزيز قيم المواطنة للأبناء
}

\author{
انتصار صالح أحمد الحلبي



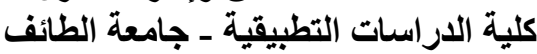 \\ المملكة العربية السعودية
}

الملب أساليب المعاملة الو الديه دور هام في تشكيل البناء النفسي للأبناء فالو الدان يمثلان نموذجاً للأبناء يلاحظونه



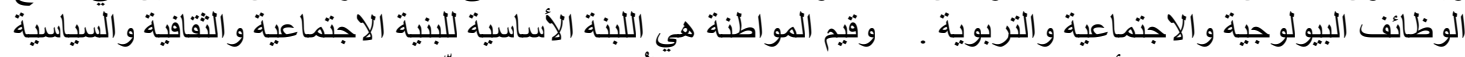











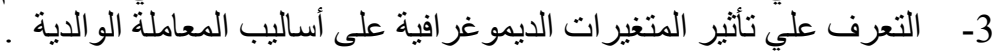






للأبناء .


1- وجود فروق ذات دلالة إحصائية بين منوسط درجات أفراد العينة في أساليب المعاملة الوالدية تبعا لمتغيرات

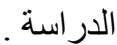










1- التّو عبة الأسرية بأهمية أسالبب المعاملة الو الدية الايجابية ، وتوفير البيئة الملائمة لما لها من أثر كبير فى تعزيز


2- تطوير المناهج وتضمين المفاهيم و المهار ات المختلفة عن تعزيز قيم المواطنة بما يتناسب مع متغيرات وتحديات



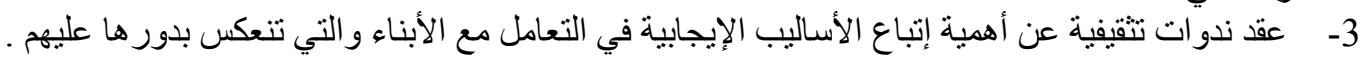

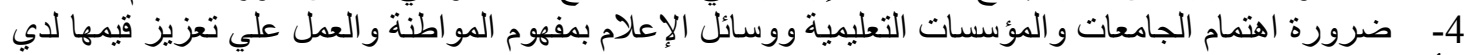
الأبناء.

5- ت تنفيذ دورات تدريبية بهذف نعزيز قيم المواطنة للأبناء حيث أنهم المستقبل و المسئولين عن تنمية المجتمع . 


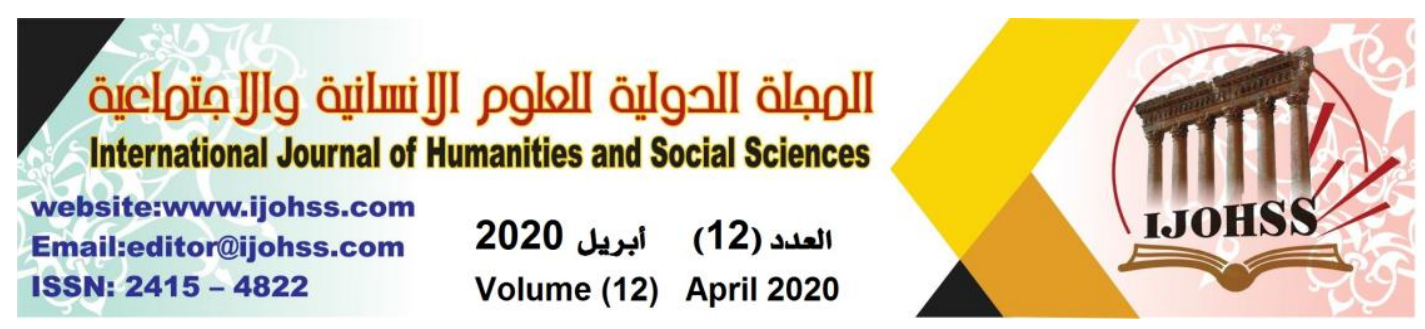

\title{
Parental Treatment Methods and Their Role in Promoting the Values of Citizenship for Children
}

\author{
Intisar Saleh Ahmed Al-Halabi \\ Assistant Professor of Housing and Home Management \\ College of Applied Studies - Taif University \\ Saudi Arabia
}

\begin{abstract}
Parental treatment methods play an important role in shaping the psychological structure of children. Parents represent a model for children that they observe and interact with through formation. Parents are the social institution based on the principle of gender partnership in all biological, social and educational functions. The values of citizenship are the basic building block of the social, cultural, political and economic structure of society, as it is the bulwark in the face of deviation in every form, and reinforces the unified values of social construction in light of the civilizational development that we live today.

The research aims to:

1- Directing parents towards the best way to deal with their children, which helps to reinforce their citizenship values.

2- Reaching the relationship between parenting methods and its reflection on enhancing the citizenship values for children.

3- Knowing the effect of demographic variables on parental treatment methods.

4- Examining the effect of demographic variables on enhancing citizenship values for children.

5- Reaching the factors that affect the promotion of citizenship values.

6- Providing some suggestions and recommendations in light of the results of the results, which can be useful in promoting citizenship values for children.

The research found:

1- There are statistically significant differences between the mean scores of the sample in parental treatment methods according to the study variables.

2- There are statistically significant differences between the mean scores of the sample individuals in enhancing the citizenship values according to the study variables.

3- There is a correlation between the questionnaire of parental treatment methods and the question of enhancing citizenship values.

4- The difference in the participation rate of the factors affecting the parental treatment methods.

5- The difference in the percentage of participation of factors affecting the enhancement of citizenship values.

I recommend searching:

1- Family awareness of the importance of positive parenting methods, and providing the appropriate environment because of its great impact in promoting the values of citizenship.

2- Developing curricula and incorporating different concepts and skills about enhancing the values of citizenship in a way that is compatible with the changes and challenges of the current era.

3- Holding educational seminars on the importance of adopting positive methods in dealing with children, which in turn will reflect on them.

4- The need for universities, educational institutions and the media to pay attention to the concept of citizenship and work to enhance their values among children.

5- Implementing training courses with the aim of promoting citizenship values for children, as they are the future and responsible for community development.
\end{abstract}

Keywords: parental treatment, values of citizenship. 











(2011،

























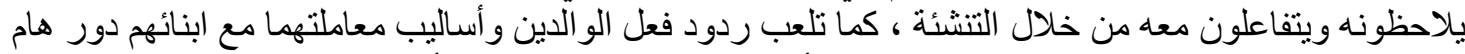

























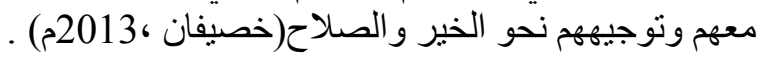

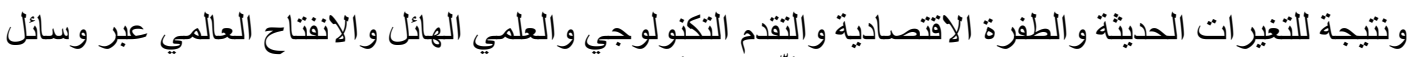

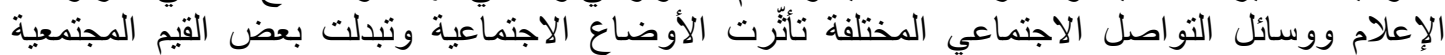

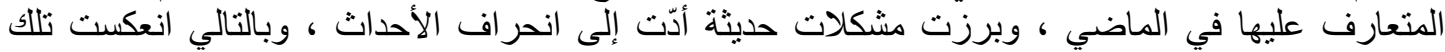







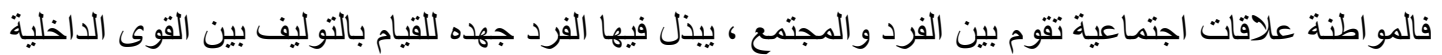

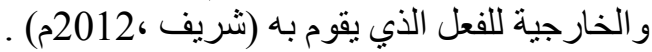










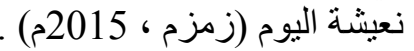





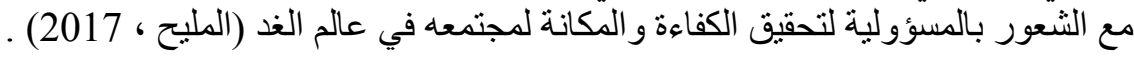



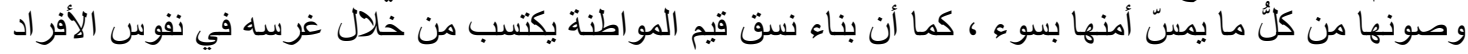



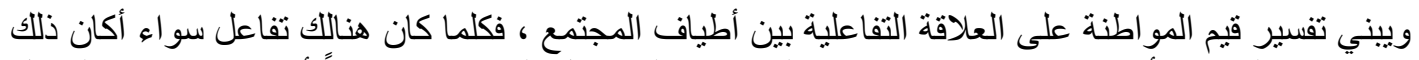







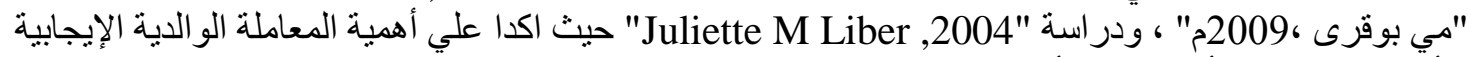







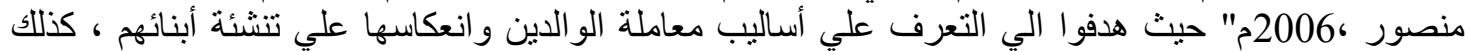

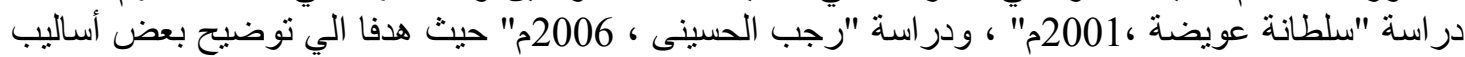

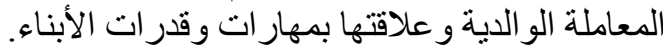

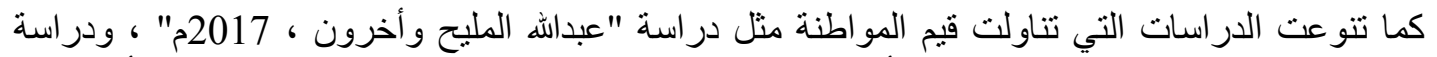
















الو الدية ودور ها في تعزيز قيم المو اطنة للأبناء .


















ز اد إحساس الأبناء بقيمتهم و أهميتهم في المحيط الاجتماعي الذي يعيشون فيه ، كلما دعم هذا من أنفسهم (النحاس الاس 


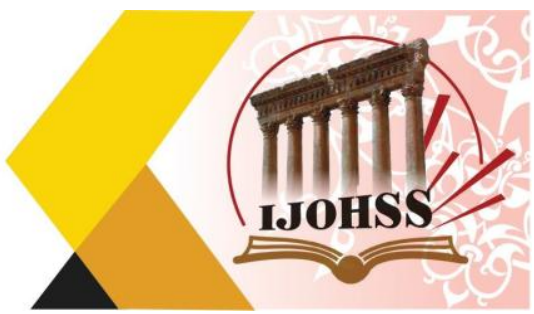

ونتيجة لما يشهده العالم اليوم من الانفجارً العلمي الهائل والثورة الكبرى في مجال التكنولوجيا ، فأصبحت

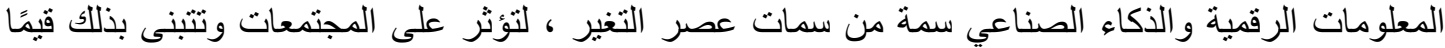

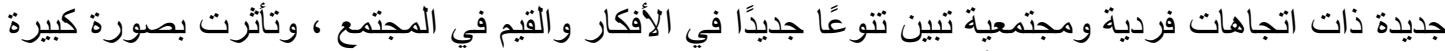

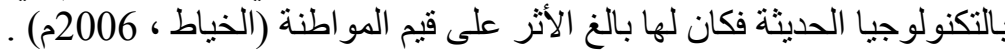

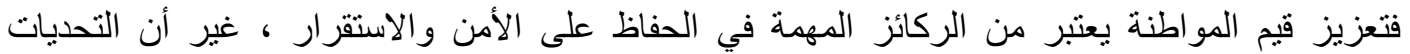

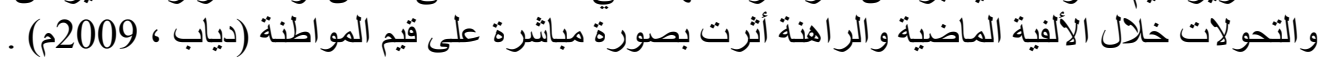

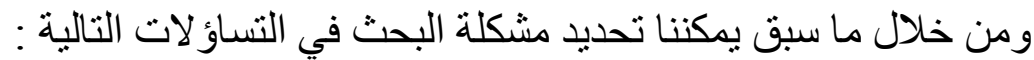

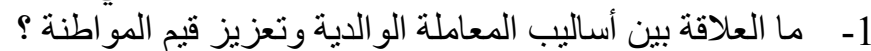

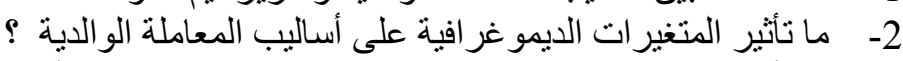



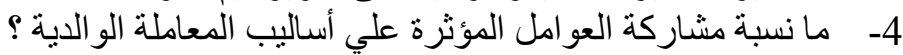

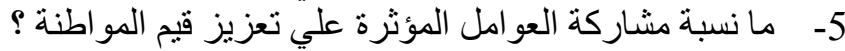

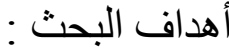

يهدف هذا البحث الي در اسة أساليب المعاملة الوالدية ودور ها في تعزيز قيم المواطنة للأبناء ، وذلك من خلال 1- - توجيه الو الدين نحو الاسلوب الامتل للتعامل مع الأبناء مما يساعد على تعزيز قيم المو اطنة لايهم .

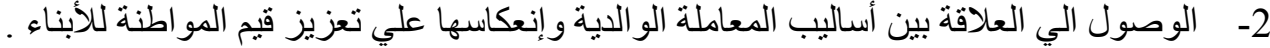

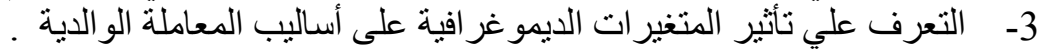

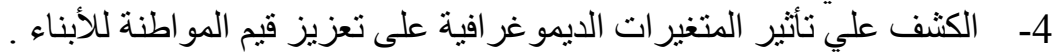
5-

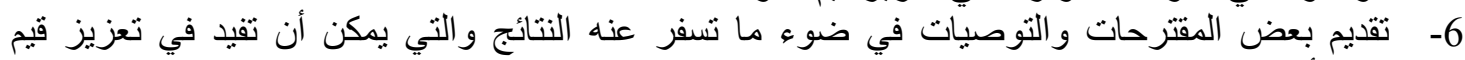

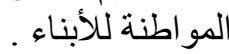

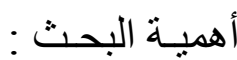

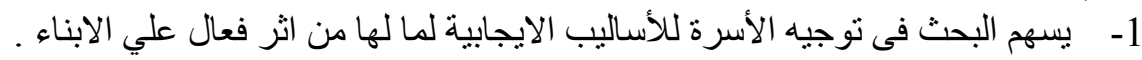

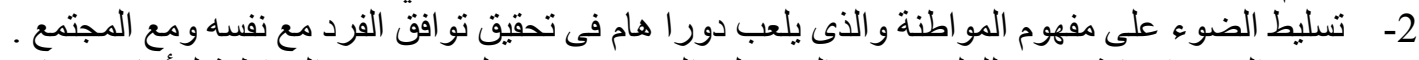

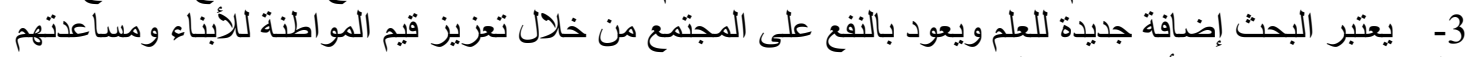

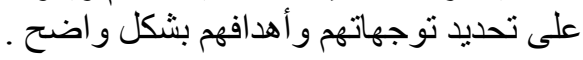

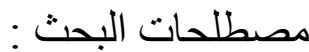

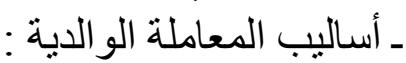

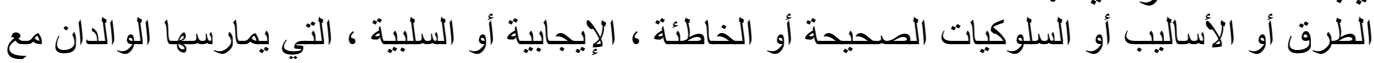



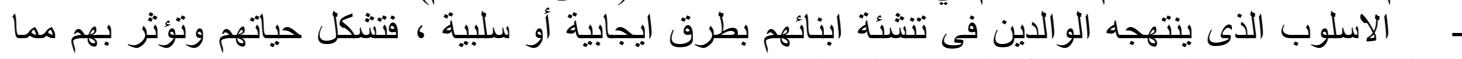

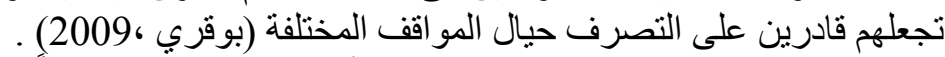

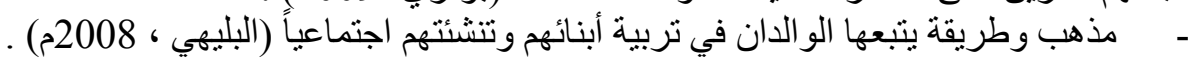
ـ وتعرف الباحثة أساليب المعاملة الو الدية إجر ائيا بأنه :

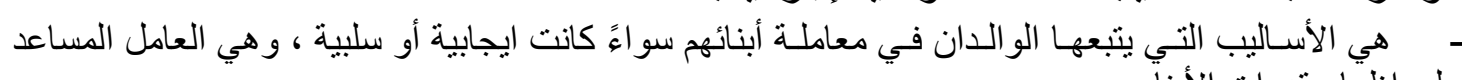

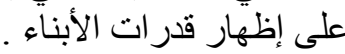

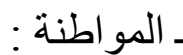

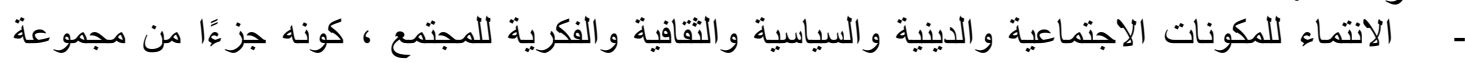

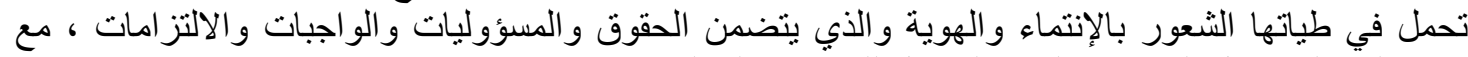
اتفاق القيم التي تمثل الهوية والالتز ام المتبادل للمشاركة الفعالة (شريف ،2012م). 


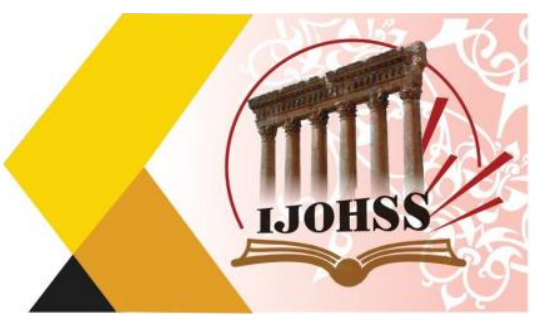

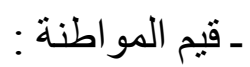

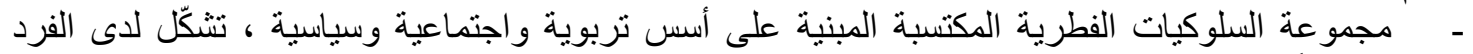

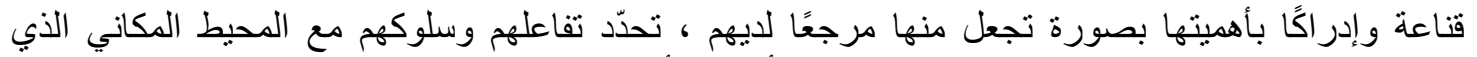

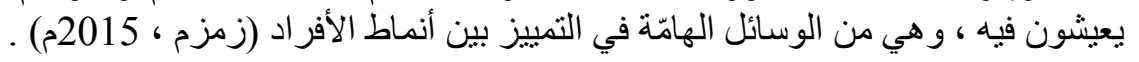

$$
\text { - وتعرف الباحثة قيم المو اطنة إجر ائيا بأنها : }
$$

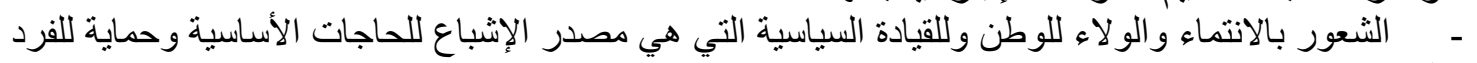

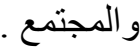

$$
\text { فروض البحث: }
$$

1- توجد فروق ذات دلالة إحصائية بين متوسط درجات أفر اد العينة في أساليب المعاملة الو الدية تبعا لمتغير ات الدر اسة. 2- توجد فروق ذات دلالة إحصائية بين منوسط درجات أفر اد العينة في تعزيز قيم المواطنة تبعا لمتغيرات الدر اسة . 3- توجد علاقة ارتباطية بين استبيان أساليب المعاملة الوالدية و استبيان تعزيز قيم المواطنة .

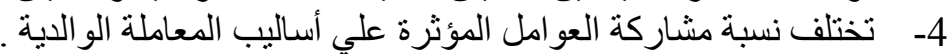

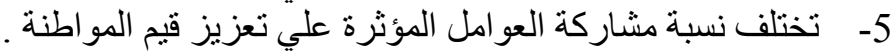

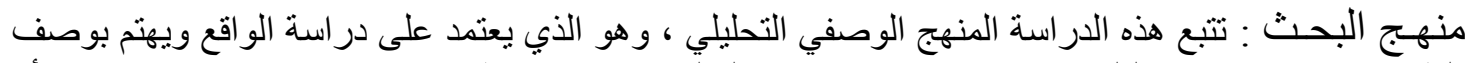

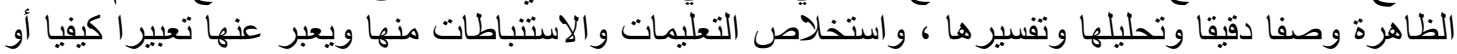

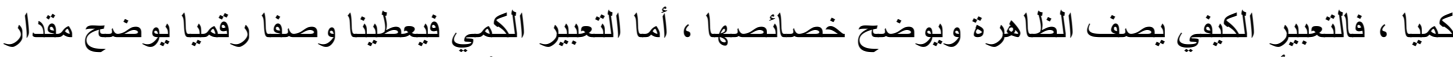

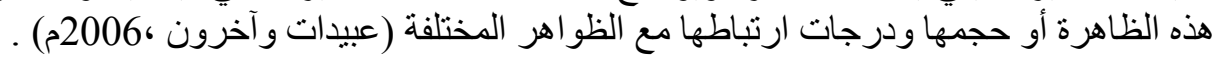

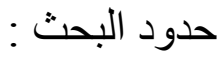
أ_الحدود المكانية : بناء على مشكلة الدر اسة وأهدافها فقد طبقت الدر اسة الميدانية على أسر سعودية في كل من

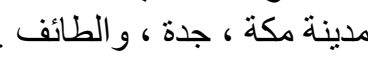
بـالحدود الزمانية : هي الفترة التي تم فيها نوزيع الاستبيان على الأسر السعودية موضوع الدراسة ، وهي

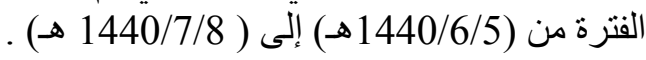

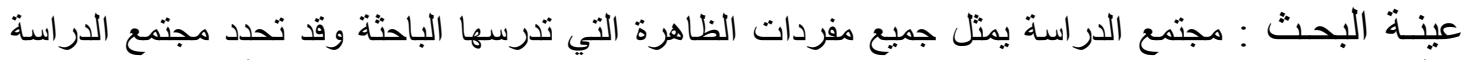

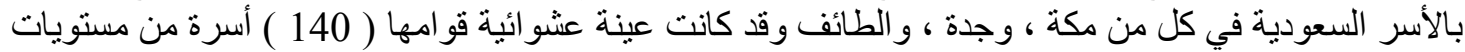

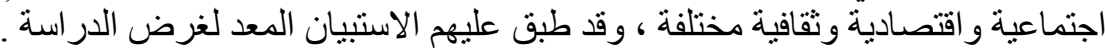

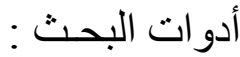
أولا : استمارة البيانات العامة : للأسر السعودية :

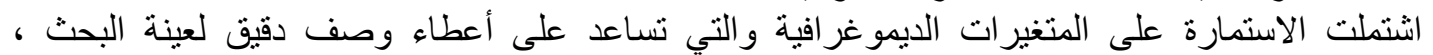

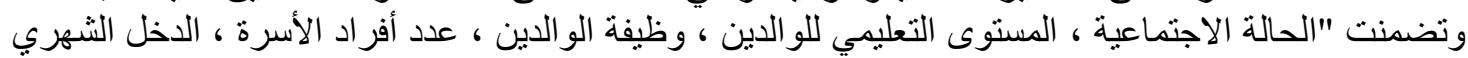

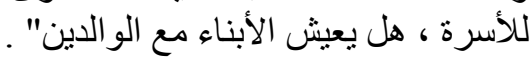

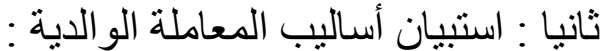

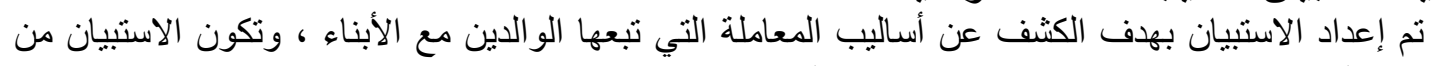

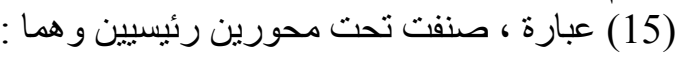

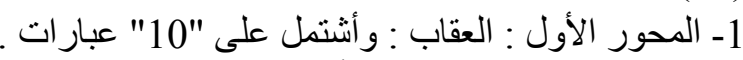

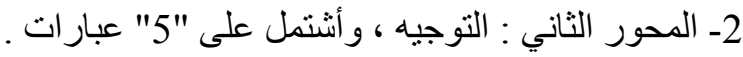
ثانيا : استبيان تعزيز قيم المواطنة : 


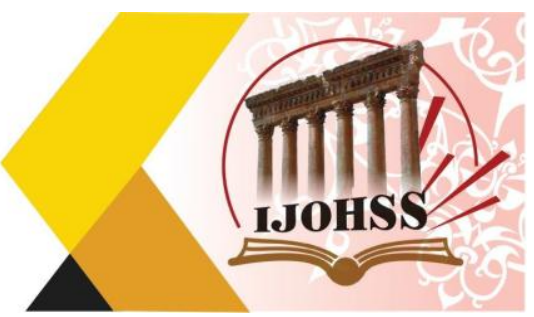

تم إعداد الاستبيان بهدف تأكيد أهمية تعزيز قيم المواطنة للأبناء بالاسرة ، و أثنتمل على "18" عبارة ، صنفت

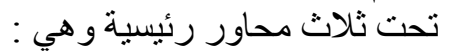

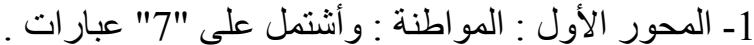

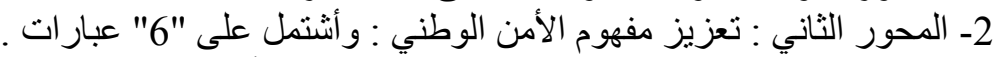

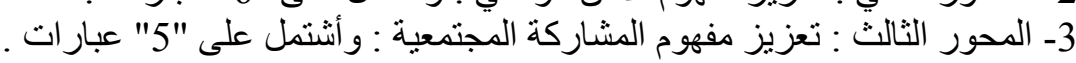

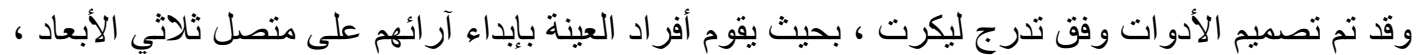

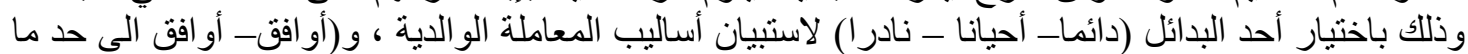

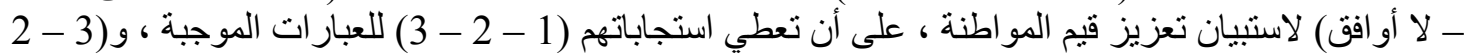

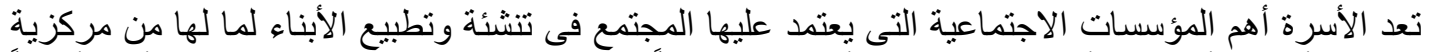

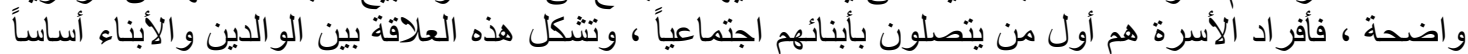

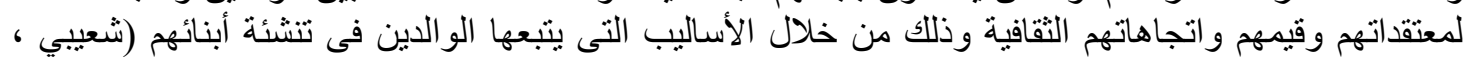

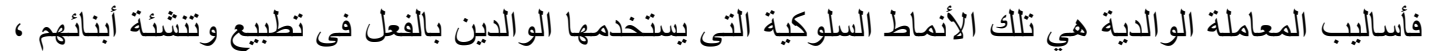

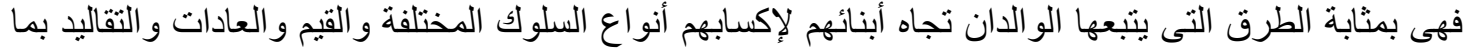

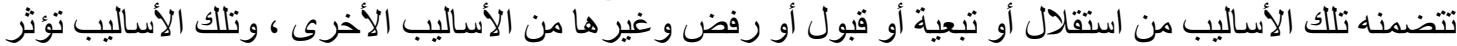

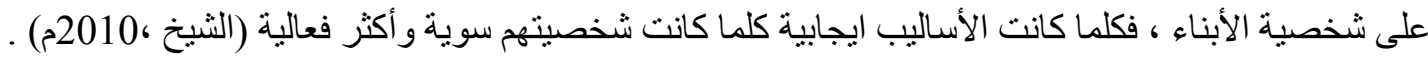

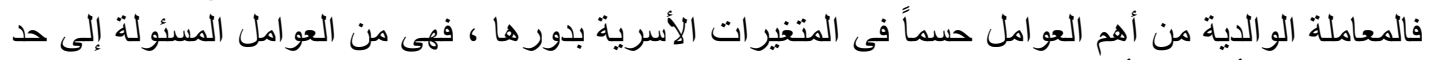

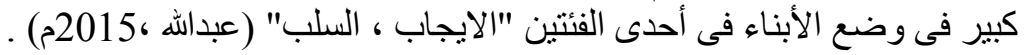

فالأساليب التربوية التى يتبعها الوالدان مع أبناءهم عبر مراحل نمو هم المختلفة نؤنثر في شخصياتهم سلباً

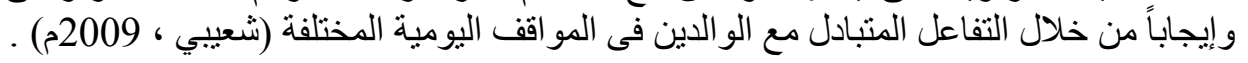

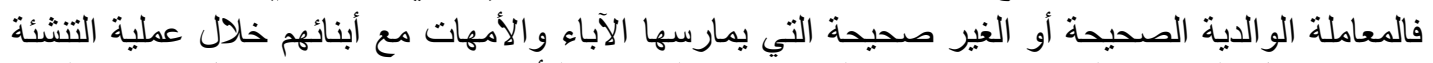
تظهر من خلال المواقف الحياتية ، وتهدف إلى تسوية سلوكهم والتأثثر في شخصياتهم بشكل سوي (الثيخ . (2010، المو اطنة : • المو اطنة لغويًا : مأخوذة من الوطن ، وهو محل الإقامة و الحماية .

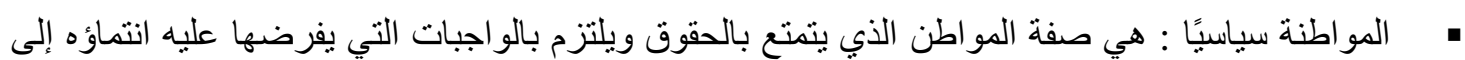
الوطن.

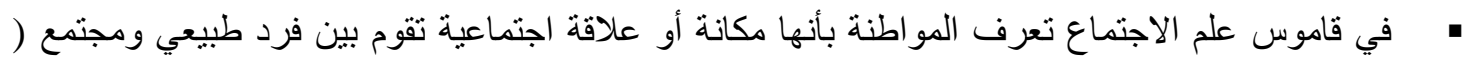

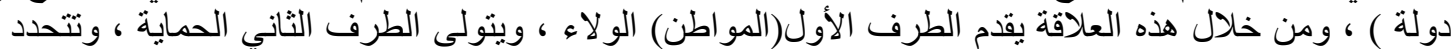
هذه العلاقة بين الفرد و الدولة عن طريق أنظمة الفرة الحكم القائمة .

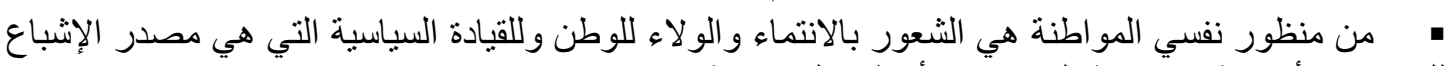

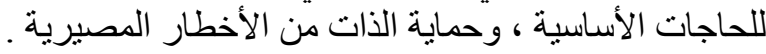

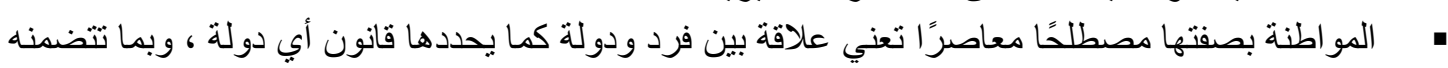

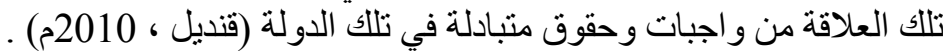
أبعاد المو اطنة :

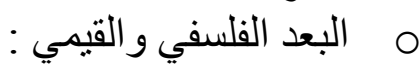

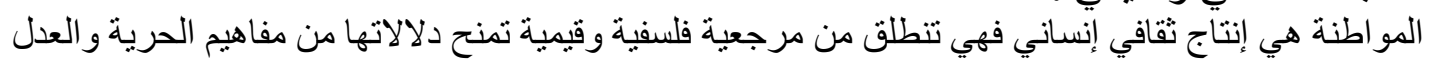

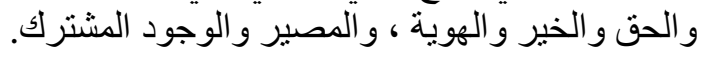




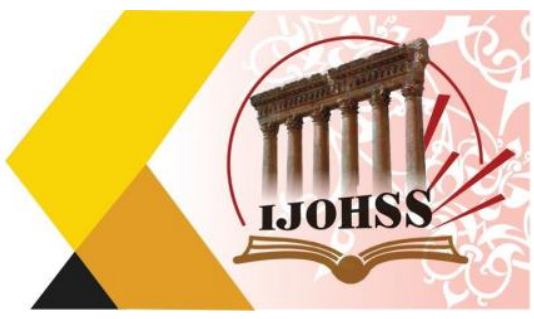

$$
\text { o }
$$

يحددها مجمو عة من القو اعد و المعايير الخاصة بحقوق الميات المو اطنة الكاملة ، كالحق في المشاركة و التقدير و اتخاذ

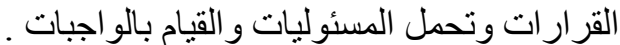

$$
\text { O البعد الاجتماعي و الثقافي : }
$$

كونها تصبح محددة لمنظومة السلوكيات و العلاقات و القيم الاجتماعية ، وتتحدد المو اطنة في أربع نظم (الانتماء ،

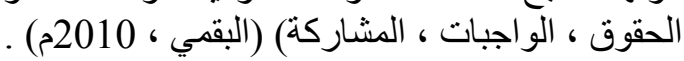

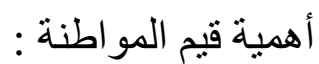

1. التعريف بالوطن وتر الثه الثقافي والديني و الاجتماعي و الاقتصادي و السياسي ، ومن ثم الإحساس الثعور

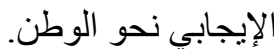
2. 3.

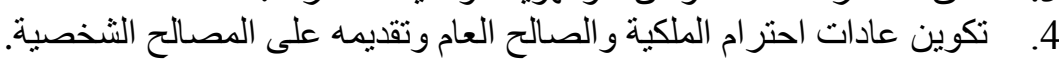

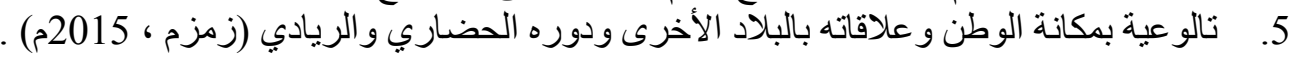

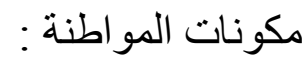

1- الانتماء : الانتماء للوطن ويجسد بالتضيحة من أجله تضحية نابعة من شعوره بحب ذلك الوطن .

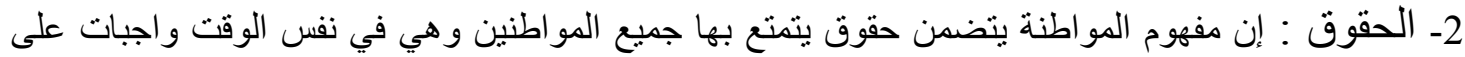

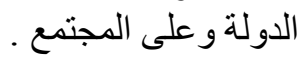
3- الو اجبات : تختلف الدول عن بعض بلنها في الو اجبات على المواطن باختلاف الفلسفة التي تقوم عيها الدولة ،

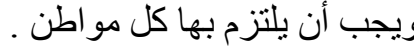
4- المشاركة المجتمعية : إن من أبرز سمات المواطنة أن يكون المواطن مشارك في الأعمال المجتمعية (آل

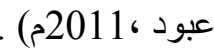
استر اتيجيات تفعيل قيم المو اطنة :

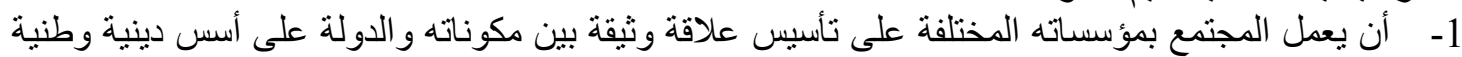

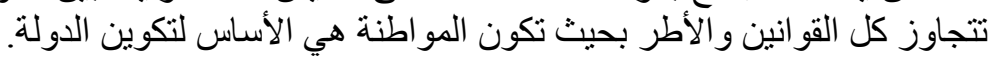

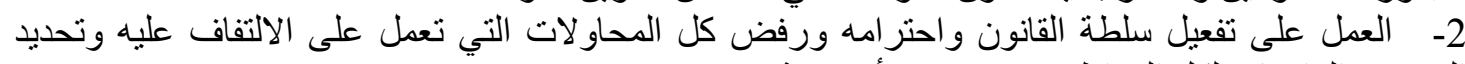

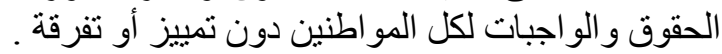

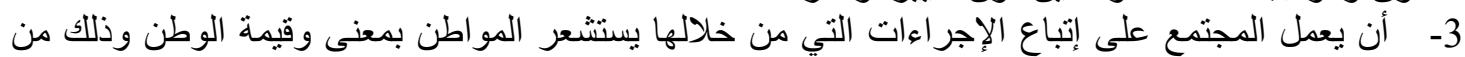

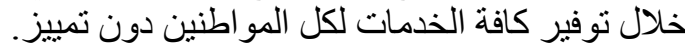

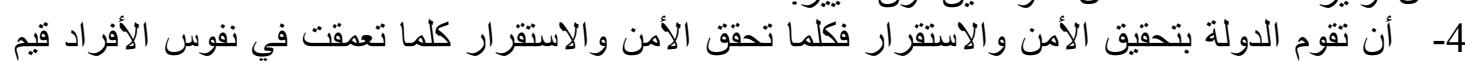

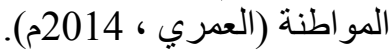

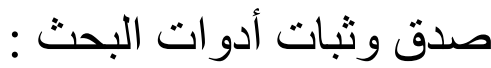

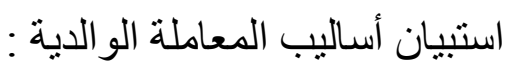

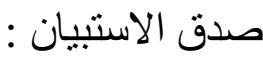

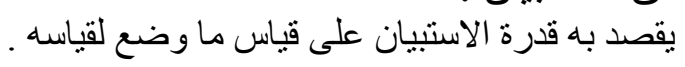

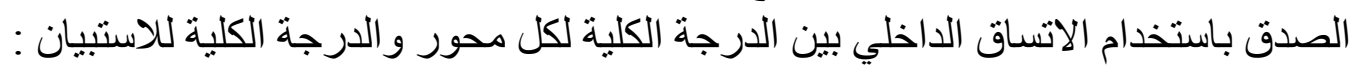

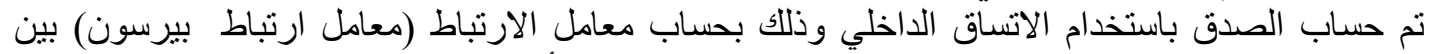

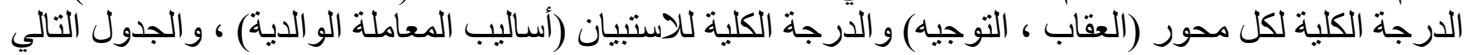



International Journal of Humanities and Social Sciences website:www.ijohss.com Email:editor@ijohss.com العدد (12) ابريل 2020 ISSN: $2415-4822$ Volume (12) April 2020

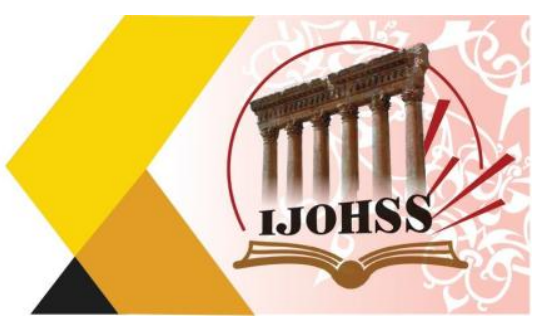

جدول (1) قيم معاملات الارتباط بين درجة كل محور ودرجة استبيان أساليب المعاملة الو الدية

\begin{tabular}{|c|c|c|}
\hline الدلالة & الارتباط & \\
\hline 0.01 & 0.836 & المحور الأول : العقاب \\
\hline 0.01 & 0.951 & المحور الثاني : التوجيه \\
\hline
\end{tabular}

يتضح من الجدول أن معاملات الارنباط كلها دالة عند مستوى ( 0.01 ) لاقتر ابها من الواحد الصحيح مما لإلها بدل على صدق وتجانس محاور الاستبيان . : الثباث:

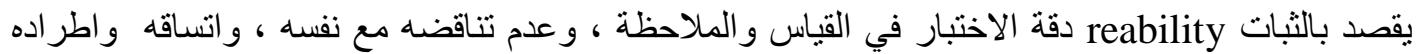

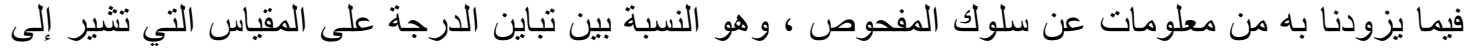

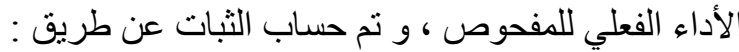

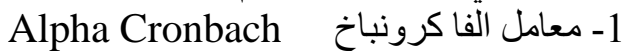

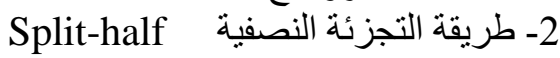

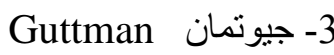

جدول (2) قيم معامل الثبات لمحاور استنيان أساليب المعاملة الو الدية

\begin{tabular}{|c|c|c|c|}
\hline جيوتمان & التجزئة النصفية & معامل الفا & المحاور \\
\hline 0.742 & $0.792-0.712$ & 0.755 & المحور الأول : العقاب \\
\hline 0.913 & $0.963-0.881$ & 0.926 & المحور الثاني : التوجيه \\
\hline 0.840 & $0.895-0.812$ & 0.851 & ثبات استبيان أساليب المعاملة الو الدية ككل \\
\hline
\end{tabular}

يتضح من الجدول السابق أن جميع قيم معاملات الثبات : معامل الفا ، التجزئة النصفية ، جيوتمان دالة عند

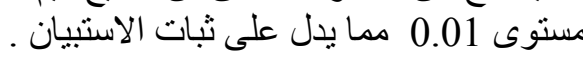

$$
\begin{aligned}
& \text { استبيان تعزيز قيم المواطنة : } \\
& \text { صدق الاستبيان : }
\end{aligned}
$$

$$
\text { يقصد به قدرة الاستبيان على قياس ما وضع لقياسه . }
$$

الصدق باستخدام الاتساق الداخلي بين الدرجة الكان الكلية لكل محور و الدارجة الكانية الكلية للاستبيان :

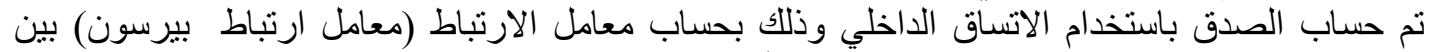

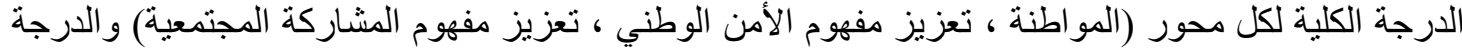

\begin{tabular}{|c|c|c|}
\hline 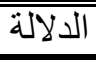 & الارنباط & \\
\hline 0.01 & 0.914 & المحور الأول : المواطنة \\
\hline 0.01 & 0.739 & المحور الثاني : تعزيز مفهوم الأمن الوطني \\
\hline 0.01 & 0.827 & المحور الثالث : تعزيز مفهوم المشاركة المجتمعية \\
\hline
\end{tabular}

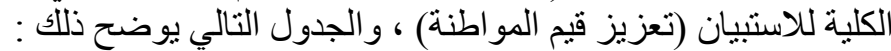

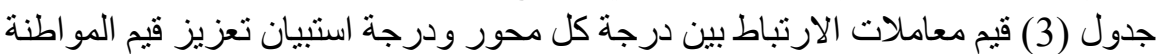

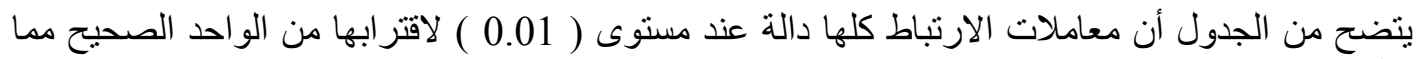

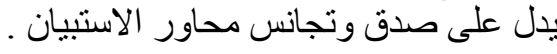

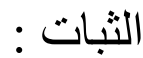

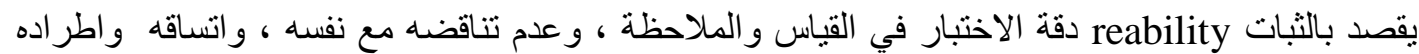

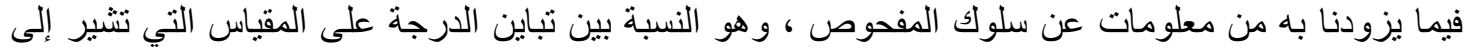

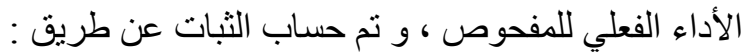



International Journal of Humanities and Social Sciences website:www.ijohss.com Email:editor@ijohss.com العدد (12) أبريل 2020 ISSN: $2415-4822$ Volume (12) April 2020

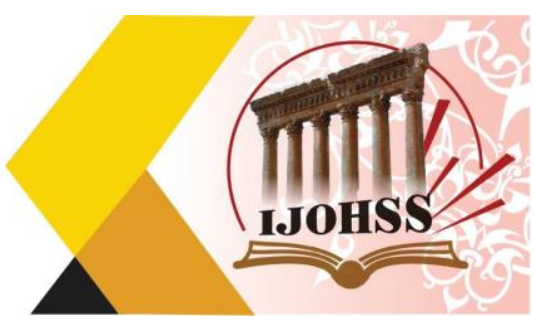

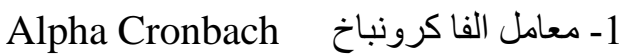

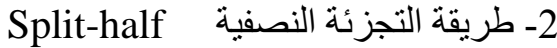
3uttman 3يونمان

جدول (4) قيم معامل الثبات لمحاور استبيان تعزيز قيم المواطنة

\begin{tabular}{|c|c|c|c|}
\hline جيوتمان & التجزئة النصفية & معامل الفا & المحاور \\
\hline 0.853 & $0.907-0.823$ & 0.862 & المحور الأول : المواطنة \\
\hline 0.773 & $0.820-0.740$ & 0.789 & المحور الثاني : تعزيز مفهوم الأمن الوطني \\
\hline 0.891 & $0.945-0.863$ & 0.905 & المحور الثالث : تعزيز مفهوم المشاركة المجتمعية \\
\hline 0.820 & $0.879-0.792$ & 0.833 & ثبات استبيان تعزيز قيم المو اطنة ككل \\
\hline
\end{tabular}

يتضح من الجدول السابق أن جميع قيم معاملات الثبات : معامل الفا ، التجزئة النصفية ، جيوتمان دالة عند مستوى 0.01 مما يدل على ثبات الاستبيان . وصف عينة البحث : استمارة البيانات العامة : مئات الانيان البيانات العامة : ت البة

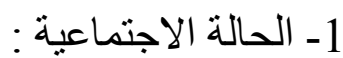
يوضح الجدول (5) و الثنكل البياني رقم (1) توزيع أفر اد عينة البحث تبعا لمتغير الحالة الاجتماعية

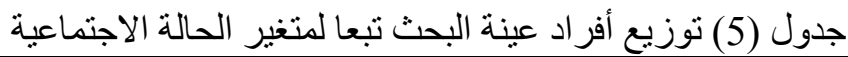

\begin{tabular}{|c|c|c|}
\hline النسبة\%\% & العدد & الحالة الاجتماعية \\
\hline$\% 57.9$ & 81 & متزوج \\
\hline$\% 17.1$ & 24 & مطلق \\
\hline$\% 25$ & 35 & أرمل \\
\hline \% \%100 & 140 & المجموع \\
\hline
\end{tabular}

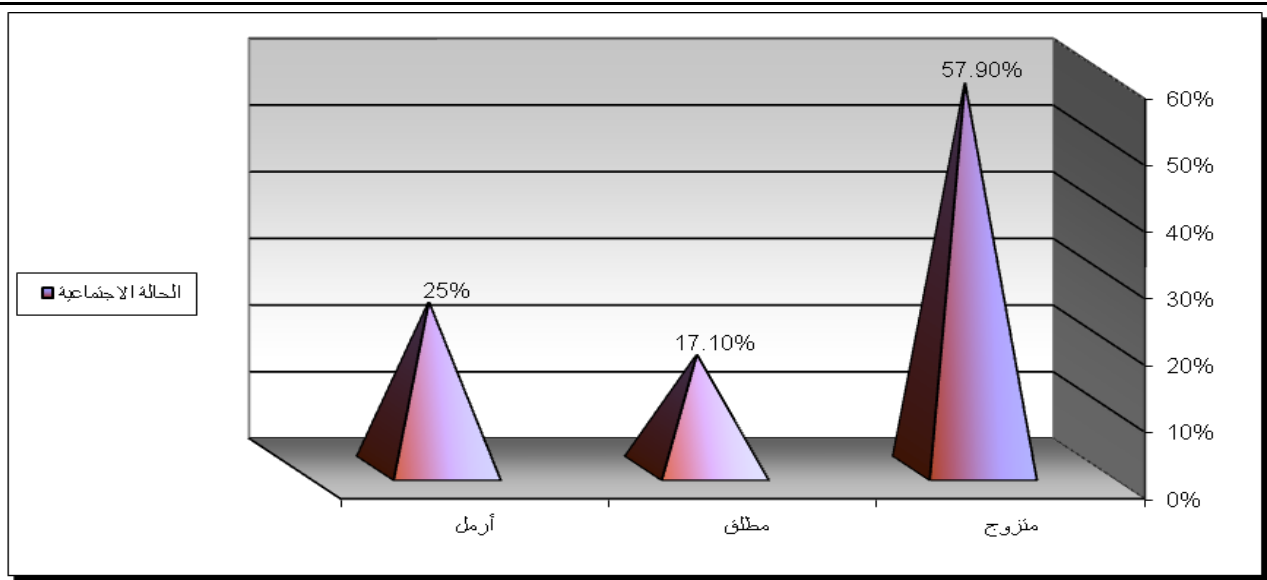

شكل (1) يوضح توزيع أفراد عينة البحث تبعا لمتغير الحالة الاجتماعية

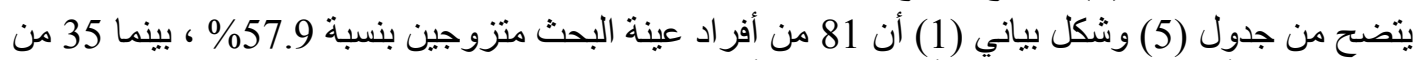
أفر اد عينة البحث أر امل بنسبة 25\% ، و وأخير ا 24 من أفر اد عينة البحث مطلقين بنسبة 17.1 \%

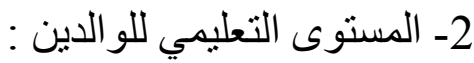
يوضح الجدول (6) وآلثكل البياني رقم (2) توزيع أفر اد عينة البحث تبعا لمتغير المستوى التعليمي للوالدين جدول (6) توزيع أفراد عينة البحث تبعاً لمتغير المستوى التعليمي للوالدين الدين 
المجلة الحولية اللعلوم الآسسانية والإمتماعية International Journal of Humanities and Social Sciences website:www.ijohss.com Email:editor@ijohss.com ISSN: $2415-4822$

$\begin{array}{ll}2020 & \text { العدد (12) } \\ \text { Volume (12) April } 2020\end{array}$

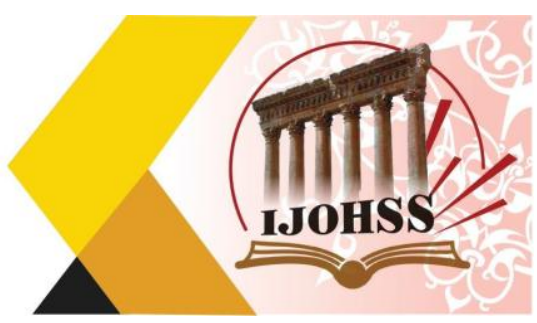

\begin{tabular}{|c|c|c|c|c|}
\hline \multicolumn{2}{|c|}{ الأم } & \multicolumn{2}{|c|}{ الأب } & \multirow{2}{*}{ المستوى التعليمي للو الدين } \\
\hline النسبة\%\% & العدد & 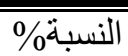 & العدد & \\
\hline 017.9 & 25 & \%10.7 & 15 & الثهادة الابتدائية \\
\hline$\% 14.3$ & 20 & $\% 17.1$ & 24 & الثهادة المتوسطة \\
\hline$\% 27.1$ & 38 & $\% 28.6$ & 40 & الثهادة الثانوية \\
\hline$\% 40.7$ & 57 & $\% 43.6$ & 61 & الثشهادة الجامعية / ماجستير ، دكتور اه \\
\hline$\% 100$ & 140 & $\%$ \%100 & 140 & المجموع \\
\hline
\end{tabular}

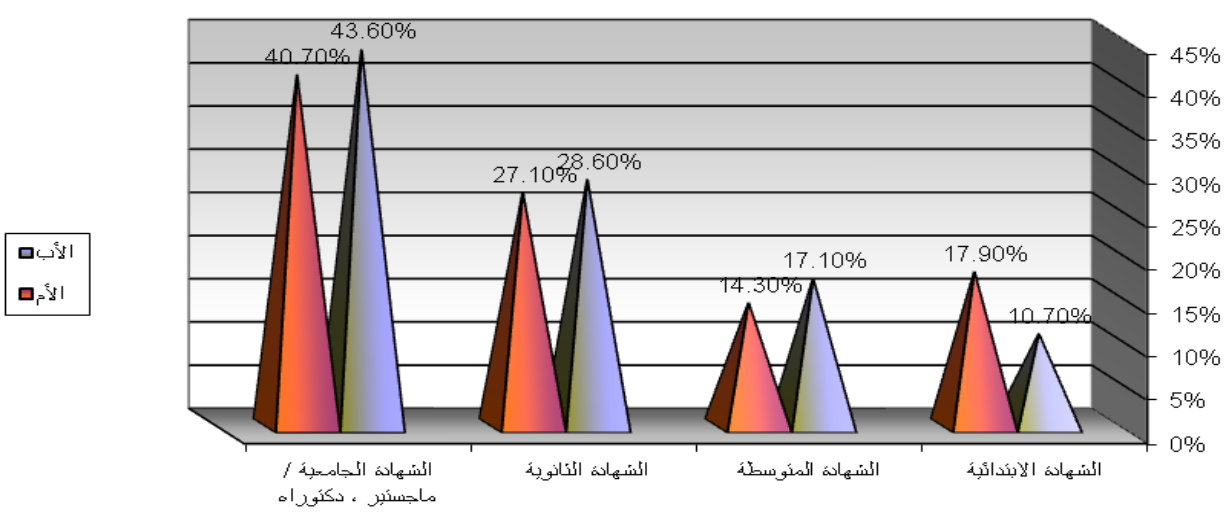

شكل (2) يوضح توزيع أفر اد عينة البحث تبعاً لمتغير المستوى التعليمي للو الدين

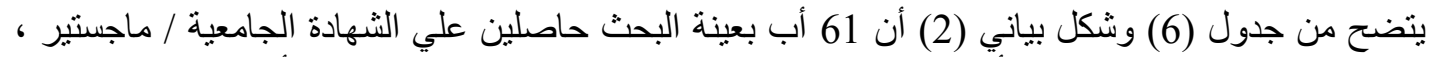

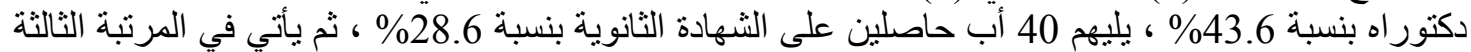

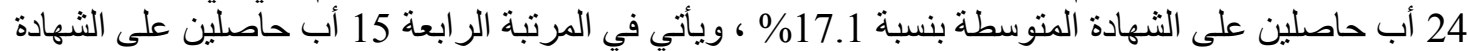

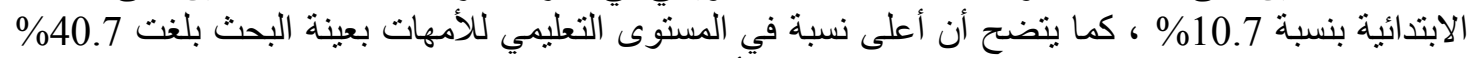

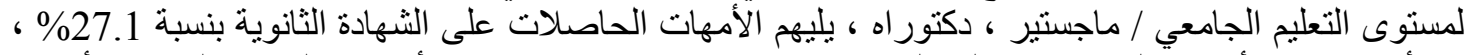

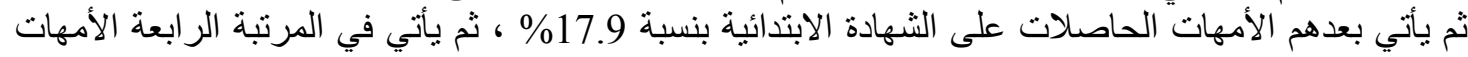

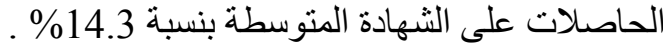

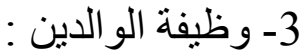

بوضح الجدول (7) و الثكل البياني رقم (3) توزيع أفر اد عينة البحث تبعا لمتغير وظيفة الو الدين جدول (7) نوزيع أفر اد عينة البحث تبعا لمتغير وظيفة الو الدين

\begin{tabular}{|c|c|c|c|c|}
\hline \multicolumn{2}{|c|}{ الأم } & \multicolumn{2}{|c|}{ الأب } & \multirow{2}{*}{ وظبفة الو الدين } \\
\hline النسبة\%\% & العدد & النسبة\%\% & العدد & \\
\hline \%60.7 & 85 & $\%$ \%50.7 & 71 & وظيفة حكو مية \\
\hline$\% 26.4$ & 37 & $\% 30$ & 42 & قطاع خاص \\
\hline$\% 12.9$ & 18 & $\% 19.3$ & 27 & أعمال حرة \\
\hline$\% 100$ & 140 & $\% 100$ & 140 & المجموع \\
\hline
\end{tabular}


المجلة الحولية اللعلوم الإنسانية والإمتاعية International Journal of Humanities and Social Sciences website:www.ijohss.com Email:editor@ijohss.com العدد (12) ابريل 2020 ISSN: $2415-4822$ Volume (12) April 2020
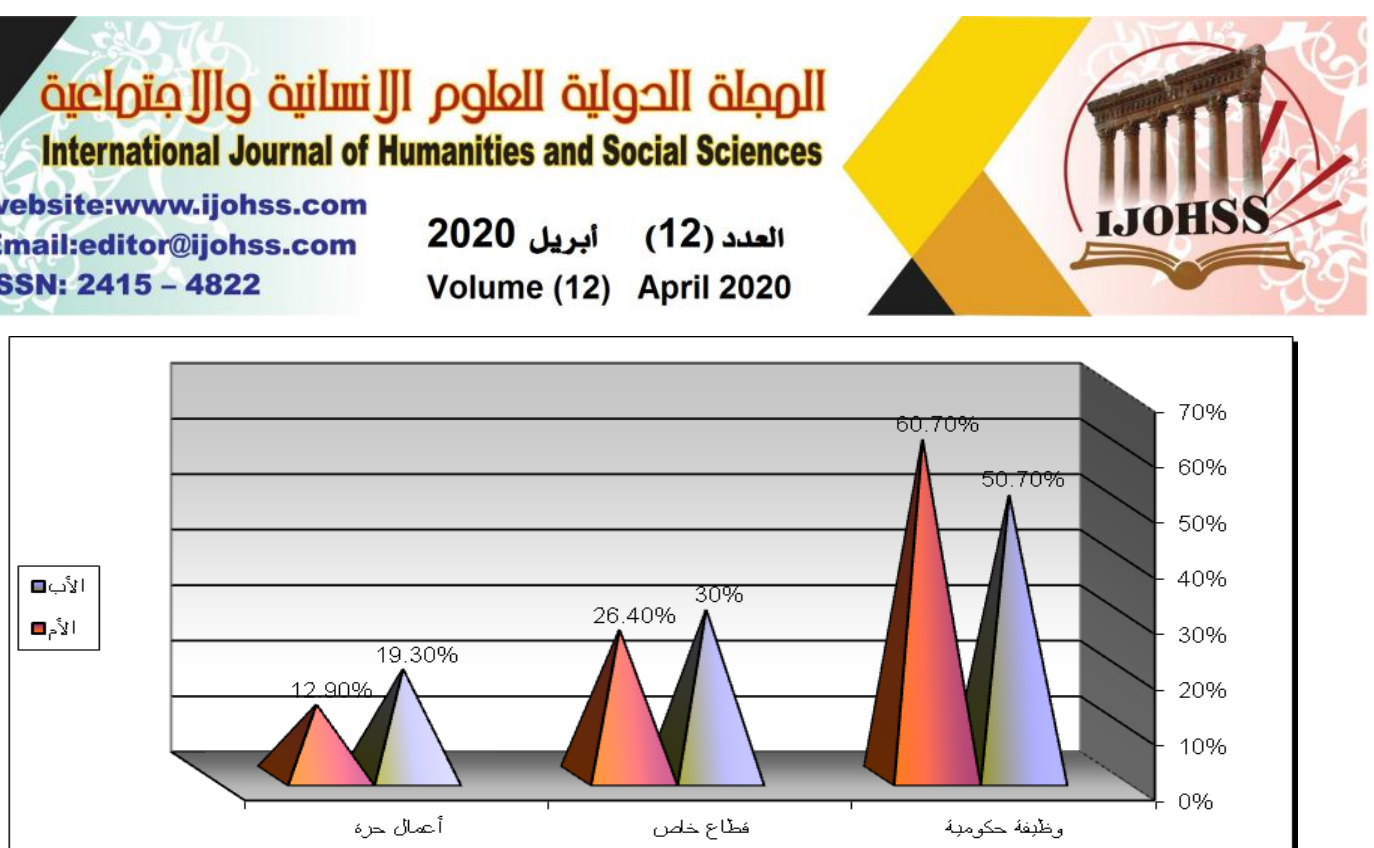

شكل (3) يوضح توزيع أفر اد عينة البحث تبعا لمتغير وظيفة الو الدين

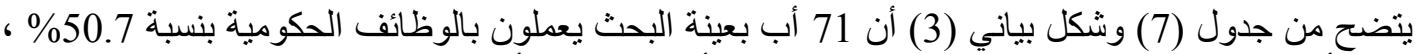

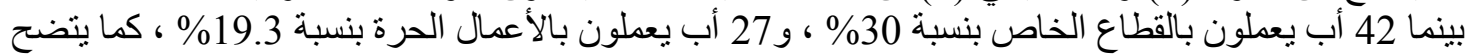

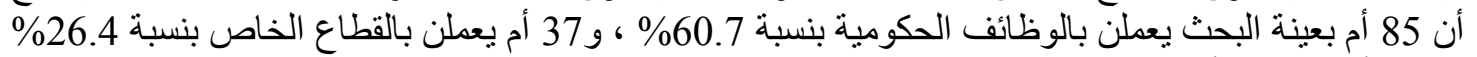

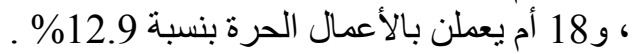

يوضح الجدول (8) و الثكل البياني رقم (4) توزيع أسر عينة البحث تبعاً لعدد أفر ادها 4- عدد أفر اد الأسرة : والاعمال جدول (8) توزيع أسر عينة البحث تبعاً لعدد أفر ادها

\begin{tabular}{|c|c|c|}
\hline النسبة\%\% & العدد & عدد أفر اد الأسرة \\
\hline$\% 32.1$ & 45 & أققل من 4 أفر اد \\
\hline$\% 47.9$ & 67 & من 4 أفر اد الي 6 أفر اد \\
\hline$\% 20$ & 28 & من 7 أفر اد فأكثر \\
\hline \%100 & 140 & المجموع \\
\hline
\end{tabular}

口مند أفراد الأسرة:

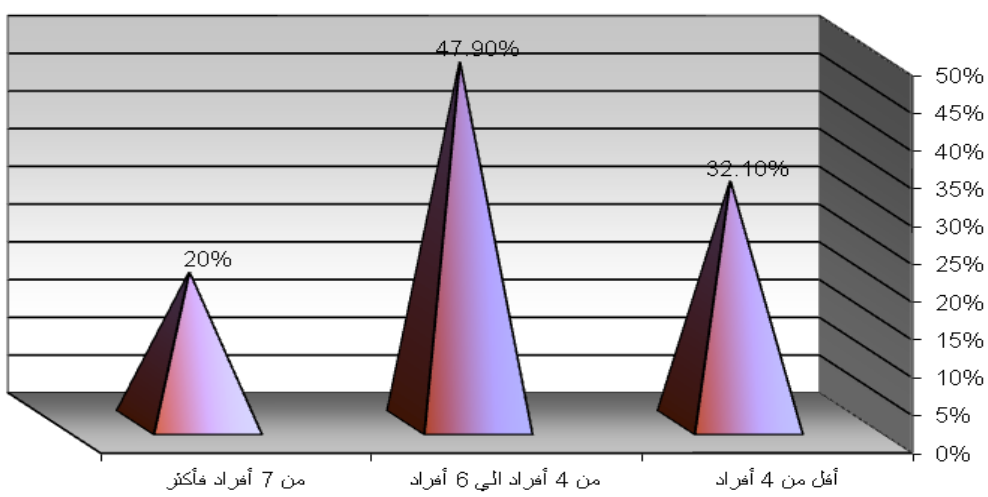

شكل (4) يوضح نوزيع أسر عينة البحث تبعأ لعدد أفرادها

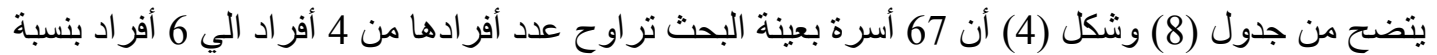

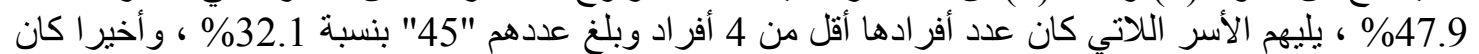

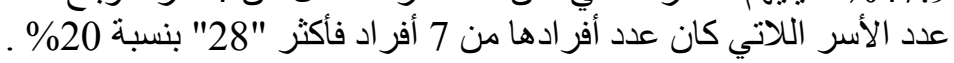

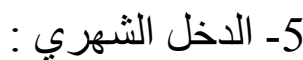

يوضـح الجدول (9) و الثكل البياني رقم (5) توزيع أسر عينة البحث وفقا لفئات الدخل المختلفة 
المجلة الحولية اللعلوم الآسانية والإمتماعية International Journal of Humanities and Social Sciences website:www.ijohss.com Email:editor@ijohss.com العدد (12) ابريل 2020 ISSN: $2415-4822$ Volume (12) April 2020

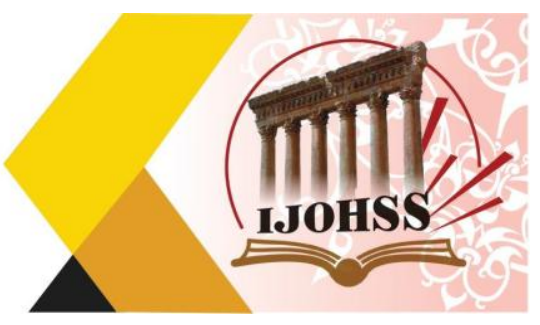

جدول (9) توزيع أسر عينة البحث وفقا لفئات الدخل المختلفة

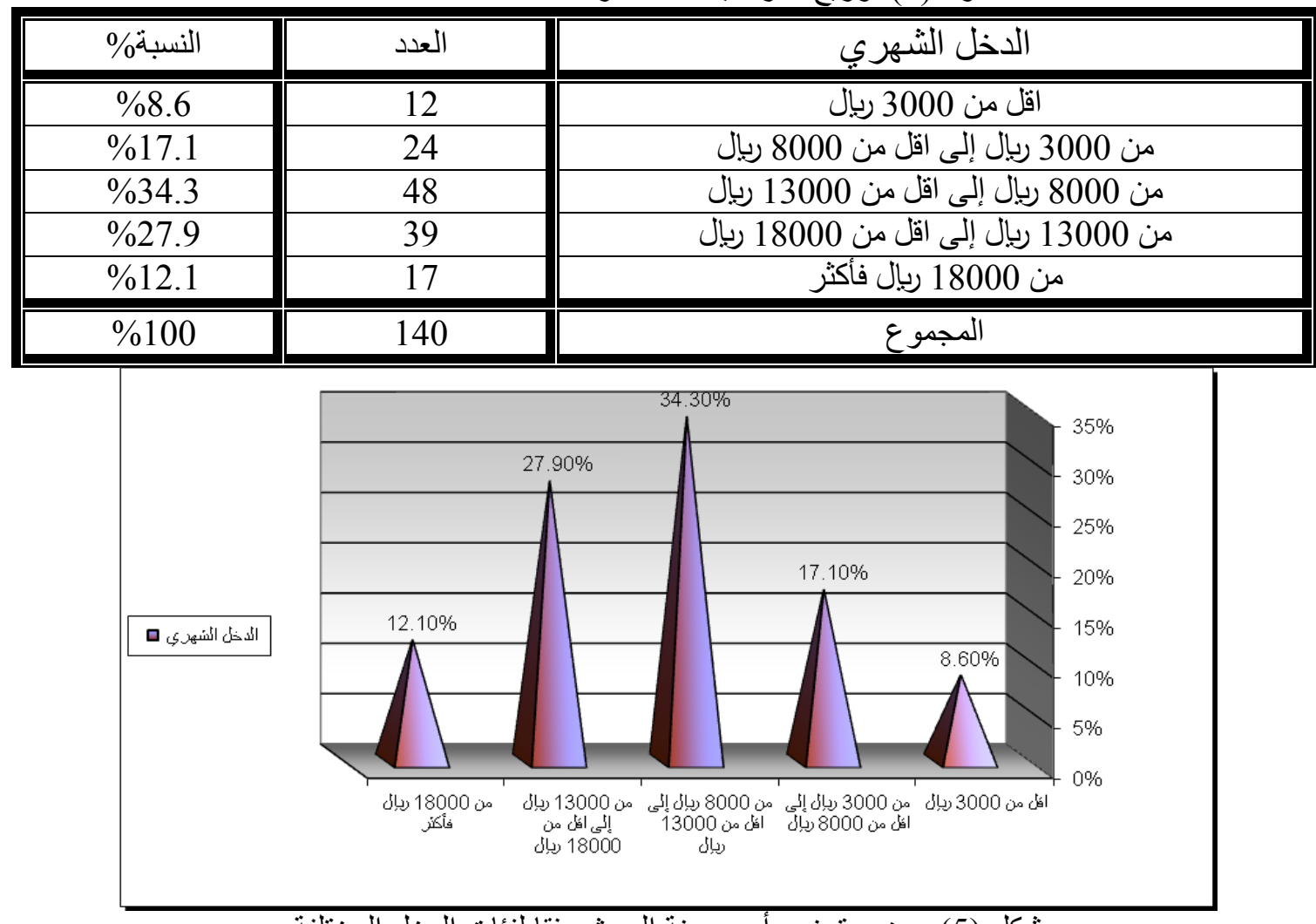

شكل (5) يوضح توزيع أسر عينة البحث وفقا لفئات الاخل المختلفة

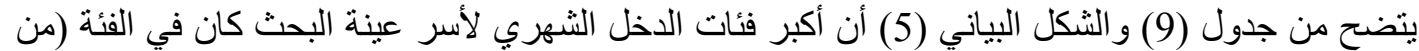

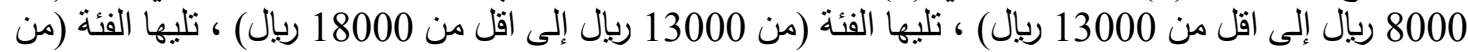

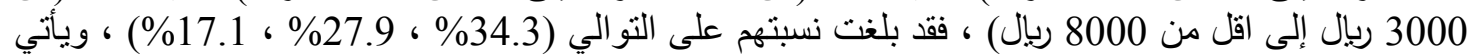
بعد ذللك الأسر ذوي الدخل (من 18000 ربال فأكثر) حيث بلغت نسبتهم 12.1\% ،

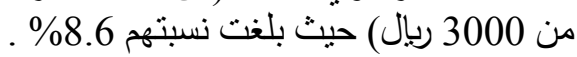

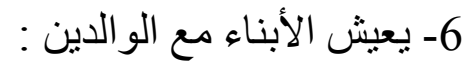
يوضح الجدول (10) و الثكل البياني رقم (6) هل يعيش الأبناء مع الو الدين الإين جدول (10) هل يعيش الأبناء مع الو الدين الابن الين الدين

\begin{tabular}{|c|c|c|}
\hline النسبة\%\% & العدد & هل يعيش الأبناء مع الوالدين \\
\hline \%880.7 & 113 & نعم \\
\hline$\% 19.3$ & 27 & $\gamma$ \\
\hline$\% 100$ & 140 & المجموع \\
\hline
\end{tabular}


المجلة الحولية اللملور الآسسانية والإمتماعية International Journal of Humanities and Social Sciences website:www.ijohss.com Email:editor@ijohss.com العدد (12) ابريل 2020 ISSN: $2415-4822$
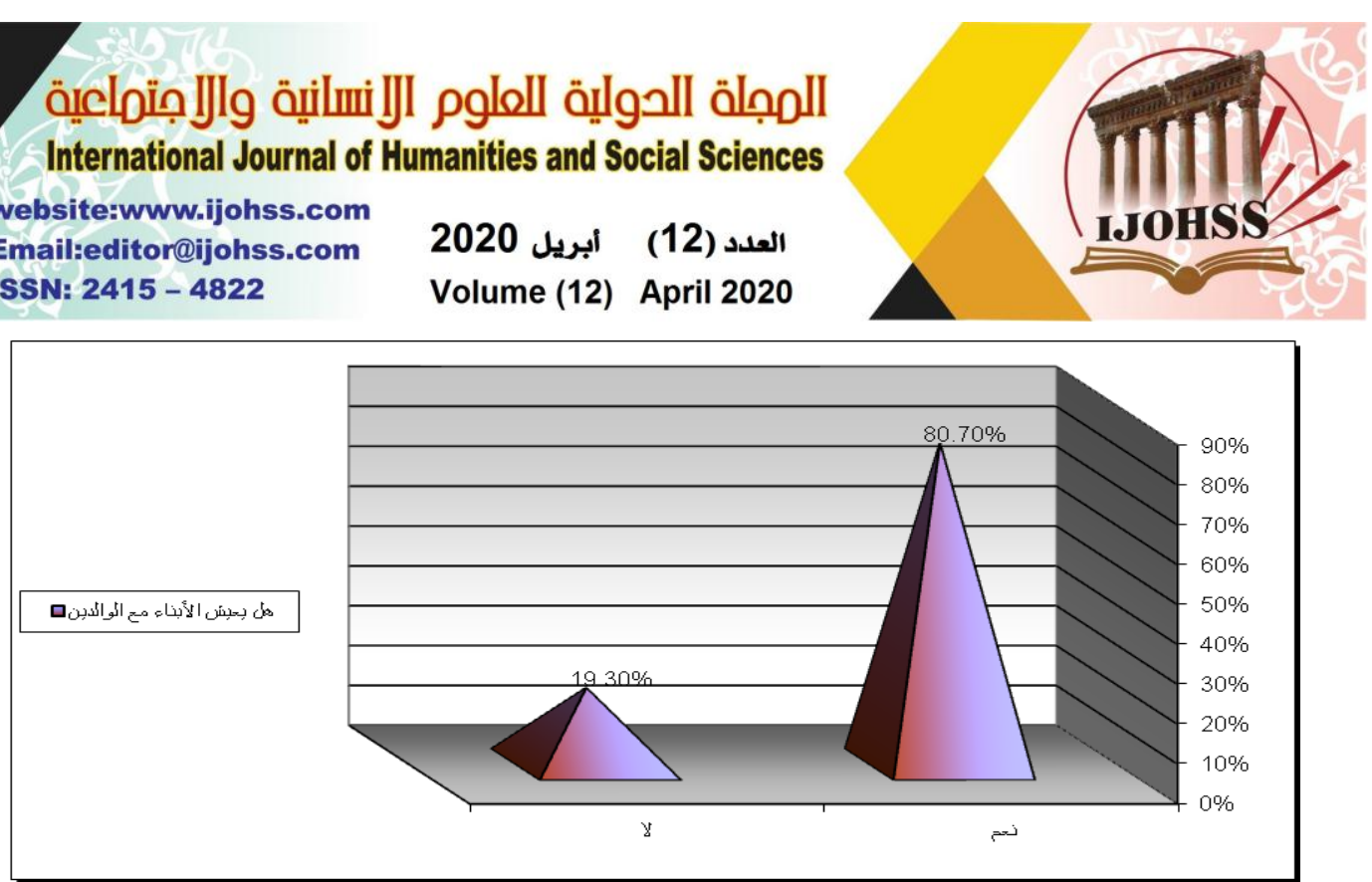

شكل (6) يوضح هل يعيش الأبناء مع الو الدين

يتضح من جدول (10) وشكل بياني (6) أن 113 أسرة يعيش معها الأبناء بنسبة 80.7\% ، بينة بينما 27 أسرة لا يعيش معها الأبناء بنسبة 19.3 \%

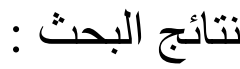

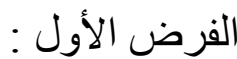

توجد فروق ذات دلالة إحصائية بين منوسط درجات أفراد العينة في أساليب المعاملة الو الدية تبعا لمتغيرات الدر اسة وللتحقق من هذا الفرض تم حساب تحليل التباين لدرجات أفر اد العينة في أساليب المعاملة الوالدية و الجداول

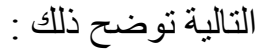

جدول (11) تحليل التباين لدرجات أفر اد العينة في أساليب المعاملة الو الدية تبعا لمتغير الحالة الاجتماعية

\begin{tabular}{|c|c|c|c|c|c|}
\hline 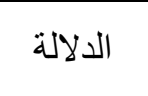 & قيمة (ف) & الحرية & متوسط المربعات & مجموع المربعات & الحالة الاجتماعية \\
\hline \multirow{3}{*}{0.0101} & \multirow{2}{*}{35.578} & 2 & 2655.834 & 5311.667 & بين المجمو عات \\
\hline & & 137 & 74.648 & 10226.758 & داخل المجمو عات \\
\hline & & 139 & & 15538.425 & المجموع \\
\hline
\end{tabular}

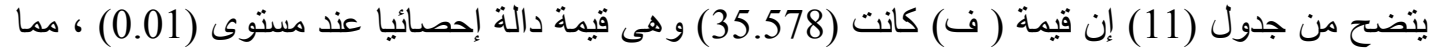

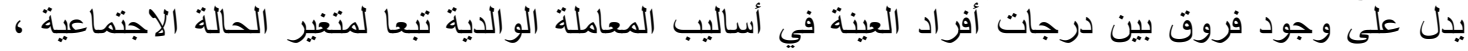

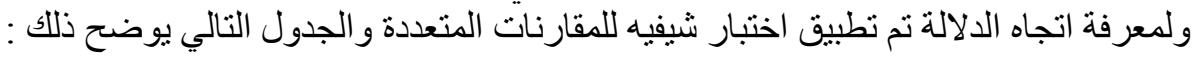
جدول (12) اختبار شيفيه للمقارنات المتعددة

\begin{tabular}{|c|c|c|c|}
\hline م = أرمل 33.277 & 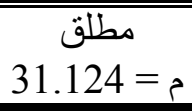 & م= متزوج & الحالة الاجتماعية \\
\hline & & - & منزوج \\
\hline & - & $* * 11.089$ & مطلق \\
\hline - & $* 2.153$ & $* * 8.936$ & أرمل \\
\hline
\end{tabular}

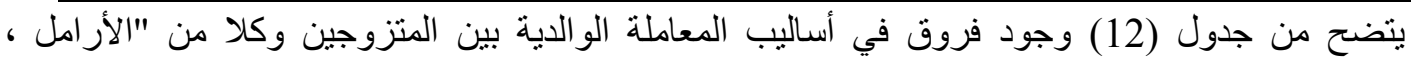

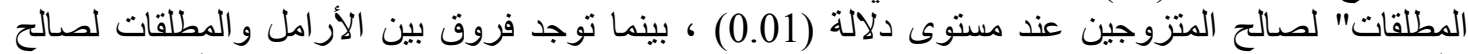

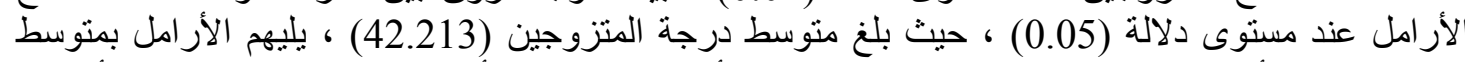

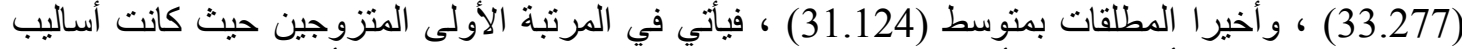
المعاملة الو الدية لديهم أفضل ، ثم الأر امل في المرتبة الثنانية ، ثم المطلقات في المرتبة الأخيرة . 
المجلة الحولية اللعلوم الآسانية والإمتاعية International Journal of Humanities and Social Sciences website:www.ijohss.com

Email:editor@ijohss.com

العدد (12) ابريل 2020

ISSN: $2415-4822$

Volume (12) April 2020

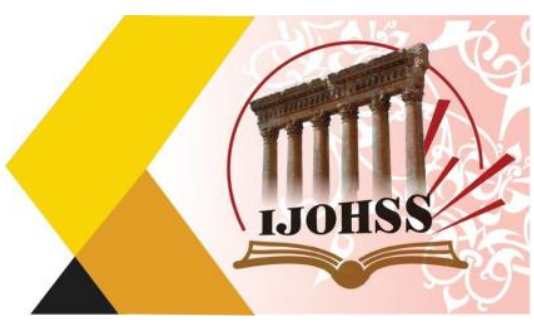

جدول (13) تحليل التباين لدرجات أفر اد العينة في أساليب المعاملة الوالدية تبعا لمتغير المستوى التعليمي للأب

\begin{tabular}{|c|c|c|c|c|c|}
\hline 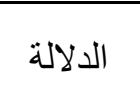 & قيمة (ف) & الحرية & متوسط المربعات & مجموع المربعات & المستوى التعليمي \\
\hline \multirow{2}{*}{0.01 دال } & \multirow{2}{*}{51.681} & 2 & 2681.281 & 5362.563 & بين المجمو عات \\
\hline & & 137 & 51.881 & 7107.702 & داخل المجمو عات \\
\hline & & 139 & & 12470.265 & المجموع \\
\hline
\end{tabular}

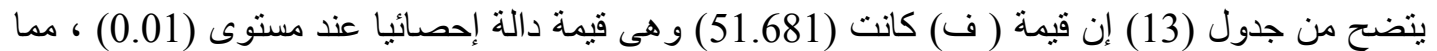

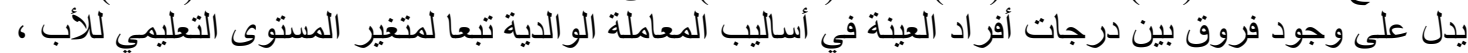

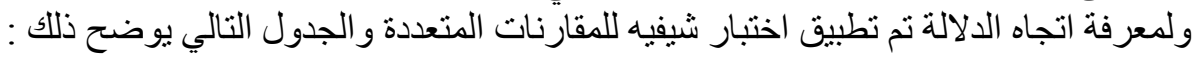
جدول (14) اختبار شيفيه للمقارنات المتعددة

\begin{tabular}{|c|c|c|c|}
\hline $\begin{array}{c}\text { م = عالي } 40.456 \\
40 .\end{array}$ & م = منوسط 28.111 & م = منخفض 20.537 & المستوى التعليمي للأب \\
\hline & & - & منخفض \\
\hline & - & $* * 7.574$ & متوسط \\
\hline - & $* * 12.345$ & $* * 19.919$ & عالى \\
\hline
\end{tabular}

يتضح من جدول (14) وجود فروق في أساليب المعاملة الو الدية بين الأباء في المستوى التعليمي العالي وكلا

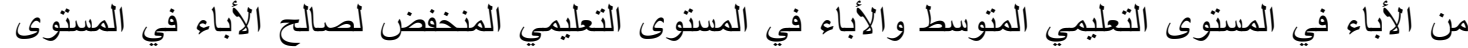

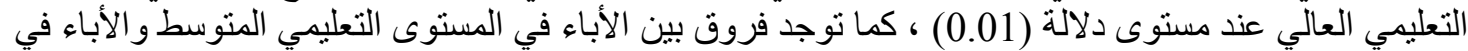

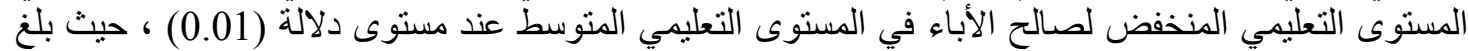

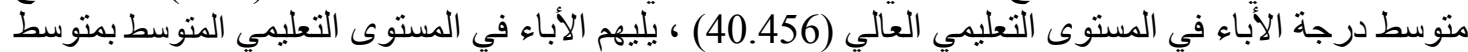

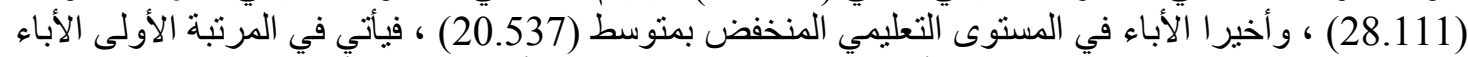

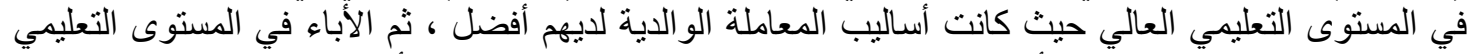

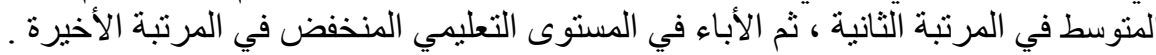

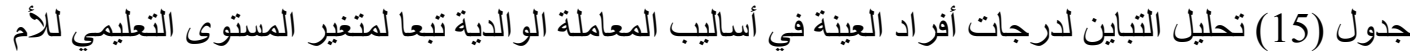

\begin{tabular}{|c|c|c|c|c|c|}
\hline 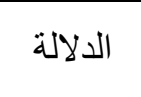 & قيمة (ف) & الحرية & منوسط المربعات & مجموع المربعات & المستوى التعليمي للأم \\
\hline \multirow{2}{*}{0.01 دال } & \multirow{2}{*}{45.374} & 2 & 2730.030 & 54560.060 & بين المجمو عات \\
\hline & & 137 & 60.168 & 8242.949 & داخل المجمو عات \\
\hline & & 139 & & 13703.009 & المجموع \\
\hline
\end{tabular}

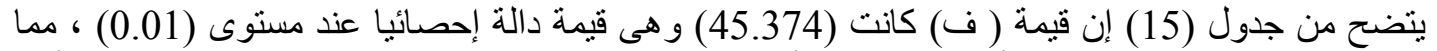

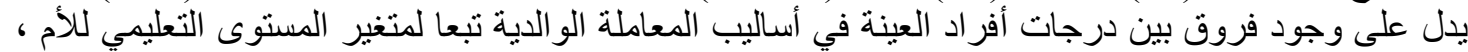

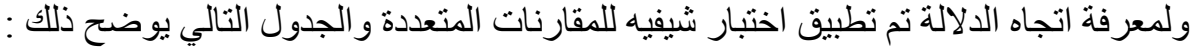
جدول (16) اختبار شيفيه للمقارنات المتعددة

\begin{tabular}{|c|c|c|c|}
\hline 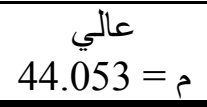 & م = متوسط 36.614 & م = منخفض 25.189 & المستوى التعليمي للأم \\
\hline & & 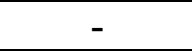 & منخفض \\
\hline & - & $* * 11.425$ & متوسط \\
\hline - & $* * 7.439$ & $* * 18.864$ & عالي \\
\hline
\end{tabular}



International Journal of Humanities and Social Sciences website:www.ijohss.com

Email:editor@ijohss.com

العدد (12) ابريل 2020

ISSN: $2415-4822$

Volume (12) April 2020

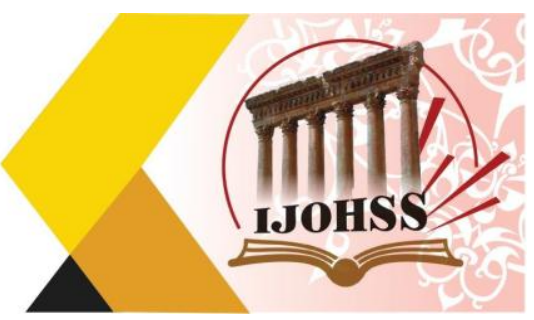

يتضح من جدول (16) وجود فروق في أساليب المعاملة الو الدية بين الأمهات في المستوى التعليمي العالي

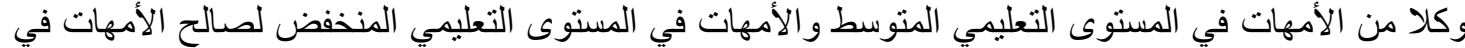

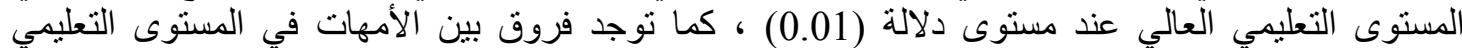

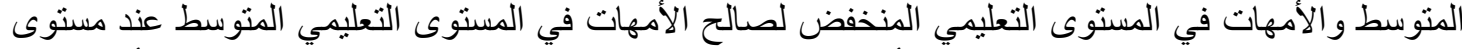

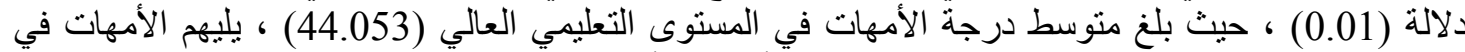

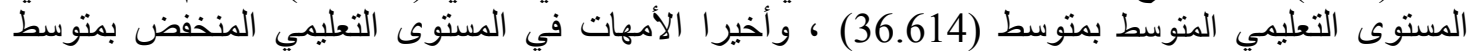

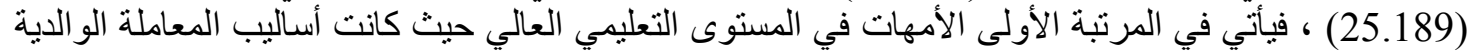

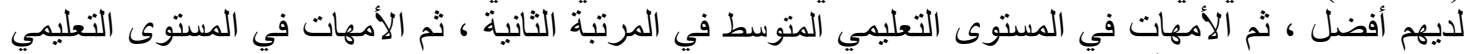
المنخفض في المرتبة الأخيرة .

جدول (17) تحليل التباين لدرجات أفر اد العينة في أساليب المعاملة الو الدية تبعا لمتغير وظيفة الأب

\begin{tabular}{|c|c|c|c|c|c|}
\hline الدلالة & قيمة (ف) & الحرية & متوسط المربعات & مجموع المربعات & وظيفة الأب \\
\hline \multirow{2}{*}{0.010} & \multirow{2}{*}{32.721} & 2 & 2629.028 & 5258.055 & بين المجموعات \\
\hline & & 137 & 80.348 & 11007.651 & داخل المجمو عات \\
\hline & & 139 & & 16265.706 & المجموع \\
\hline
\end{tabular}

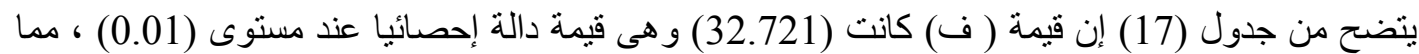

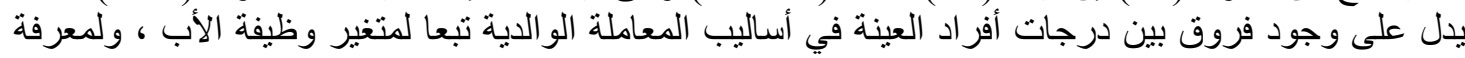

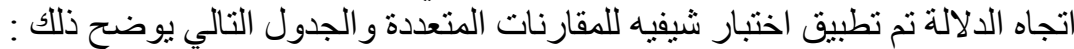
جدول (18) اختبار شيفيه للمقارنات المتعددة

\begin{tabular}{|c|c|c|c|}
\hline م = أعمال حرة 22.025 م & ق =طاع خاص 24.633 & وظيفة حكومية & وظيفة الأب \\
\hline & & 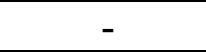 & وظيفة حكو مية \\
\hline & - & $* * 13.098$ & قطاع خاص \\
\hline - & $* 2.608$ & $* * 15.706$ & أعمال حرة \\
\hline
\end{tabular}

يتضح من جدول (18) وجود فروق في أساليب المعاملة الو الدية بين الأباء العاملين بالوظائف الحكومية وكلا

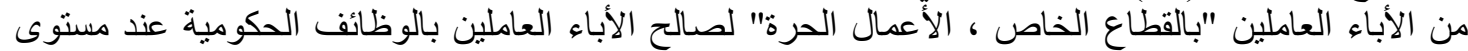

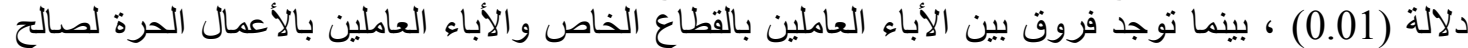

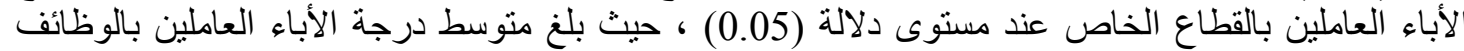

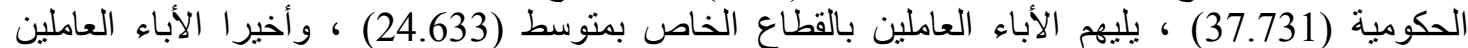

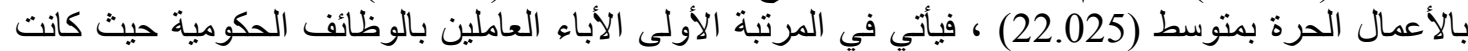

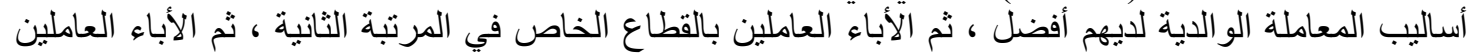

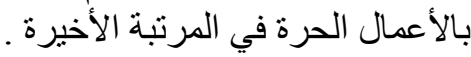

جدول (19) تحليل التباين لدرجات الفيرة أفر اد العينة في أساليب المعاملة الو الدية تبعا لمتغير وظيفة الأم

\begin{tabular}{|c|c|c|c|c|c|}
\hline 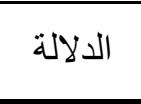 & قيمة ( ف) & الحرية & منوسط المربعات & مجموع المربعات & وظبفة الأم \\
\hline \multirow{2}{*}{0.010.} & \multirow{2}{*}{63.109} & 2 & 2822.199 & 5644.398 & بين المجمو عات \\
\hline & & 137 & 44.719 & 6126.553 & داخل المجمو عات \\
\hline & & 139 & & 11770.951 & المجموع \\
\hline
\end{tabular}



International Journal of Humanities and Social Sciences website:www.ijohss.com

Email:editor@ijohss.com

ISSN: $2415-4822$

العدد (12) (12) April 2020
Volume (12)

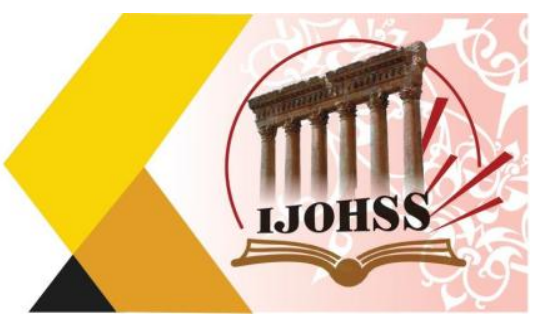

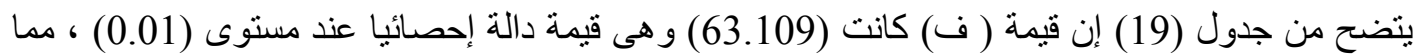

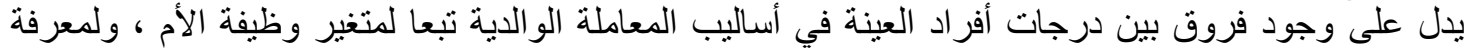

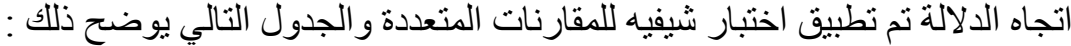
جدول (20) اختبار شيفيه للمقارنات المتعددة

\begin{tabular}{|c|c|c|c|}
\hline م = أعمال حرة 19.785 م & ق =طاع خاص 30.388 & و = =يفة حكومية & وظيفة الأم \\
\hline & & - & وظيفة حكومية \\
\hline & - & $* * 12.981$ & قطاع خاص \\
\hline - & $* * 10.603$ & $* * 23.584$ & أعمال حرة \\
\hline
\end{tabular}

ينضح من جدول (20) وجود فروق في أساليب المعاملة الو الدية بين الأمهات العاملات بالوظائف العادف الحكومية

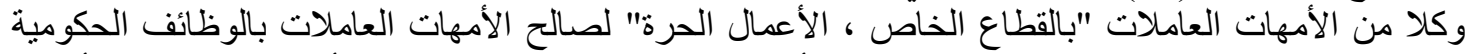

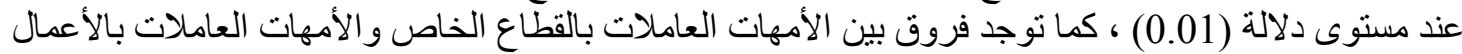

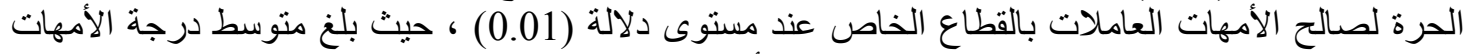

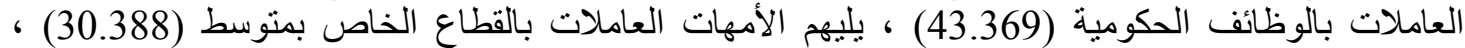

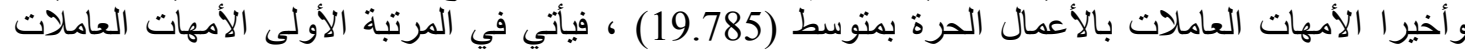

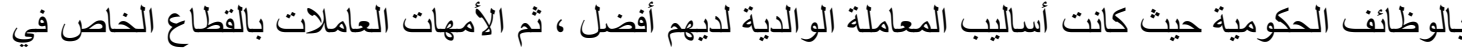

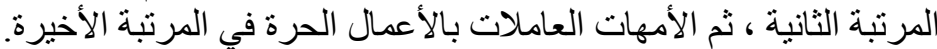

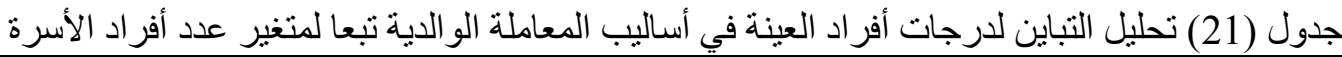

\begin{tabular}{|c|c|c|c|c|c|}
\hline الدالة الد & قيمة (ف) & الحرية & متوسط المربعات & مجموع المربعات & عدد أفر اد الأسرة \\
\hline \multirow{2}{*}{0.01 دال } & \multirow{2}{*}{41.246} & 2 & 2701.580 & 5403.160 & بين المجمو عات \\
\hline & & 137 & 65.498 & 8973.286 & داخل المجمو عات \\
\hline & & 139 & & 14376.446 & المجموع \\
\hline
\end{tabular}

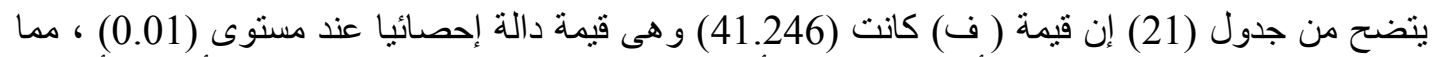

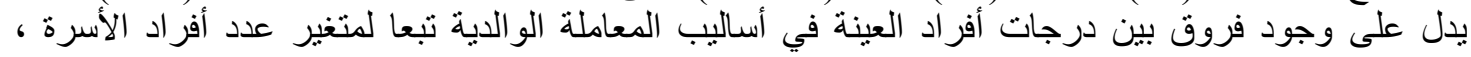

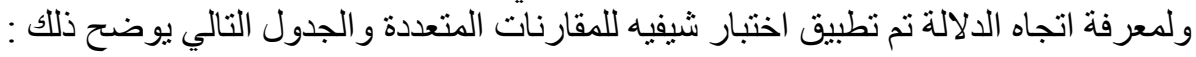

جدول (22) اختبار شيفيه للمقارنات المتعددة

\begin{tabular}{|c|c|c|c|}
\hline من 7 أفر اد فأكثر & 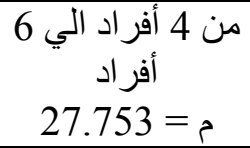 & أقل = 4 أفراد 49.901 أفل & عدد أفر اد الأسرة \\
\hline & & - & أقل من 4 أفر اد \\
\hline & - & $* * 12.148$ & من 4 أفر اد الي 6 أفر اد \\
\hline- & $* * 7.471$ & $* * 19.619$ & من 7 أفر اد فأكثر \\
\hline
\end{tabular}

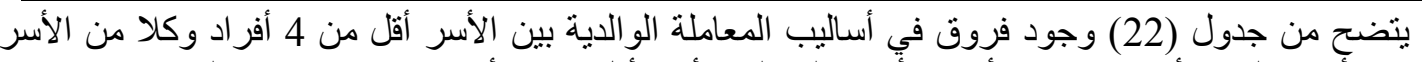

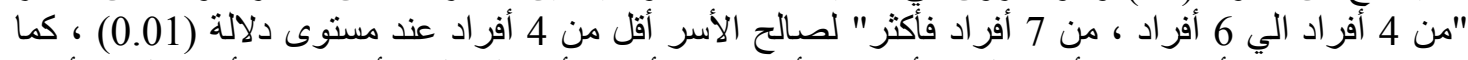

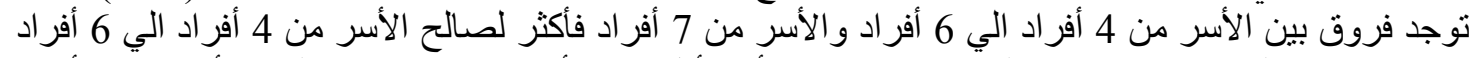

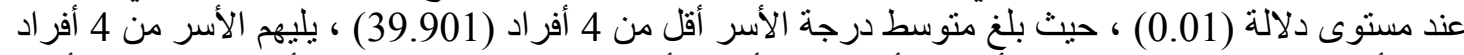

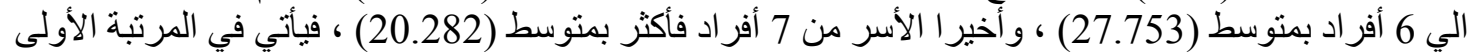

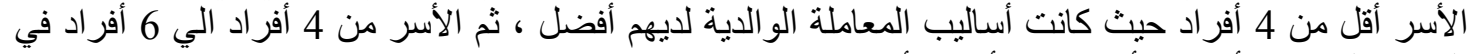
المرتبة الثانية ، و أخير ا الأسر من 7 أفر اد فأكثر . 

International Journal of Humanities and Social Sciences website:www.ijohss.com Email:editor@ijohss.com العدد (12) ابريل 2020 ISSN: $2415-4822$

Volume (12) April 2020

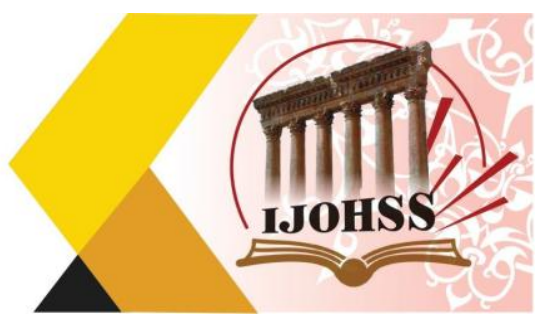

جدول (23) تحليل التباين لدرجات أفر اد العينة في أساليب المعاملة الوالدية تبعا لمتغير الدخل الثهري

\begin{tabular}{|c|c|c|c|c|c|}
\hline الدلالة الد & قيمة (ف) & الحرية & متوسط المربعات & مجموع المربعات & الاخل الثهري \\
\hline \multirow{2}{*}{ 0 01010} & \multirow{2}{*}{56.221} & 2 & 2704.368 & 5408.736 & بين المجمو عات \\
\hline & & 137 & 48.103 & 6590.067 & داخل المجمو عات \\
\hline & & 139 & & 11998.803 & المجموع \\
\hline
\end{tabular}

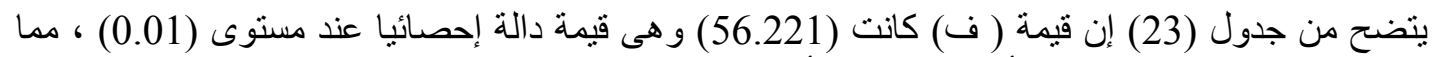

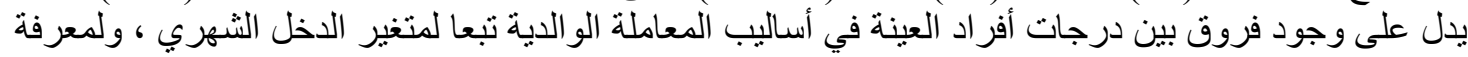

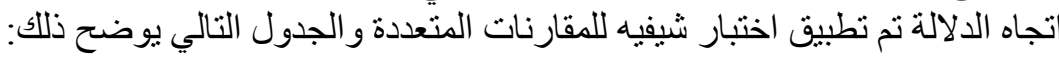
جدول (24) اختبار شيفيه للمقارنات المتعددة

\begin{tabular}{|c|c|c|c|}
\hline م = مرتفع 35.510 & م =متوسط 26.613 & م = منخفض 17.052 & الدخل الشهري \\
\hline & & - & منخفض \\
\hline & - & $* * 9.561$ & متوسط \\
\hline- & $* * 8.897$ & $* * 18.458$ & مرتفع \\
\hline
\end{tabular}

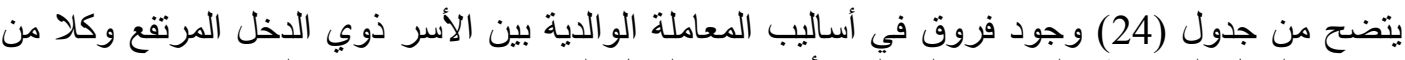

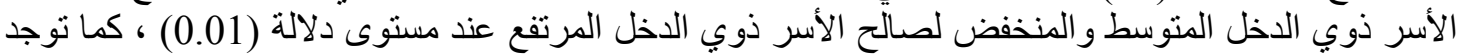

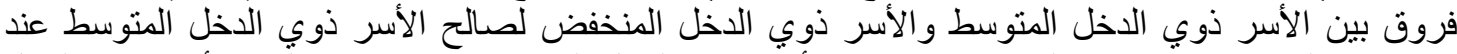

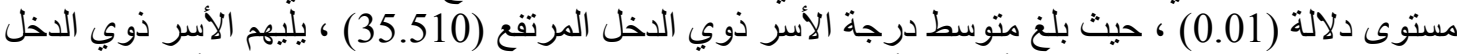

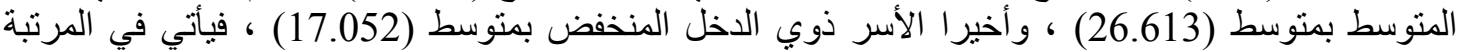

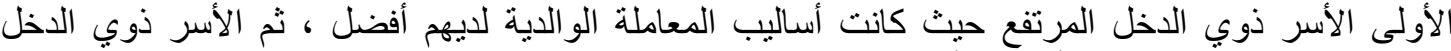

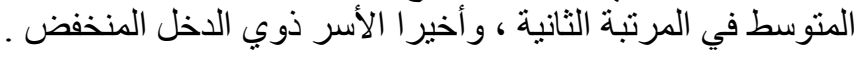

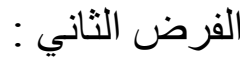
توجد فروق ذات دلالة إحصائية بين منوسط درجات أفراد العينة في تعزيز قيم المواطنة تبعا لمتغيرات الدر اسة وللتحقق من هذا الفرض تم حساب تحليل التباين لدرجات أفر اد العينة في تعزيز قيم المواطنة والجداول التالية

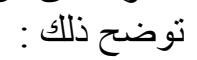

جدول (25) تحليل التباين لدرجات أفر اد العينة في تعزيز قيم المو اطنة تبعا لمتغير الحالة الاجتماعية

\begin{tabular}{|c|c|c|c|c|c|}
\hline 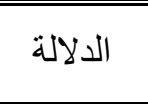 & قيمة (ف) & الحرجية & متوسط المربعات & مجموع المربعات & الحالة الاجتماعية \\
\hline \multirow{3}{*}{0.01 دال } & \multirow{2}{*}{58.254} & 2 & 2800.708 & 5601.417 & بين المجمو عات \\
\hline & & 137 & 48.078 & 6586.651 & داخل المجمو عات \\
\hline & & 139 & & 12188.068 & المجموع \\
\hline
\end{tabular}

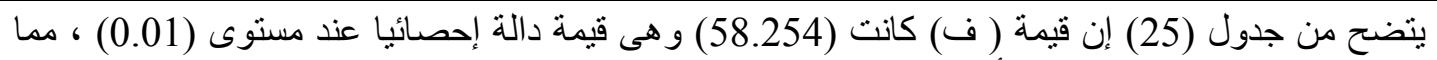

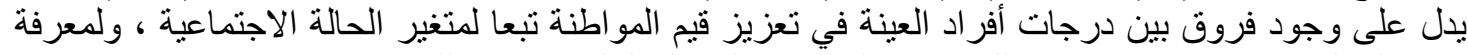

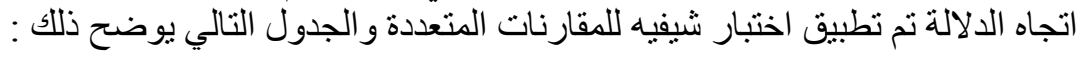


المجلة الحولية اللعلوم الآسانية والإمتماعية International Journal of Humanities and Social Sciences website:www.ijohss.com Email:editor@ijohss.com العدد (12) ابريل 2020 ISSN: $2415-4822$ Volume (12) April 2020

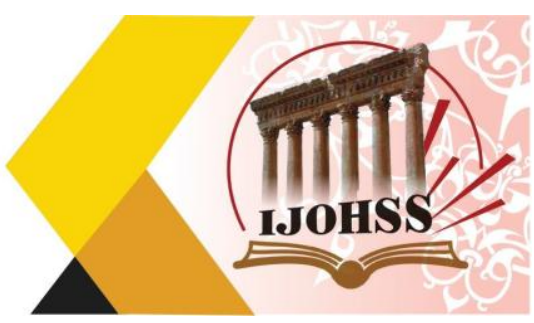
جدول (26) اختبار شيفيه للمقارنات المتعددة

\begin{tabular}{|c|c|c|c|}
\hline م = أرمل & م = مطلق 33.110 & م = متزوج & الحالة الاجتماعية \\
\hline & & - & مثزوج \\
\hline & - & $* * 17.148$ & مطلق \\
\hline- & $* * 9.128$ & $* * 8.020$ & أرمل \\
\hline
\end{tabular}

يتضح من جدول (26) وجود فروق في تعزيز قيم المواطنة بين المتزوجين وكلا من "الأرامل ، المطلقات

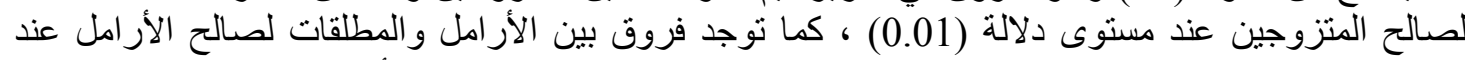

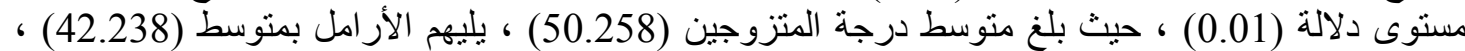
و أخيرا المطلقات بمتوسط (33.110) ، فيأتي في المرتبة الأولى المنزوجين حيث كان تعزيز قيم المواطنة الاطنة لديهم

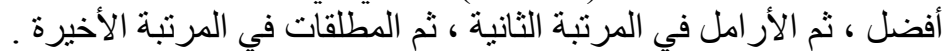

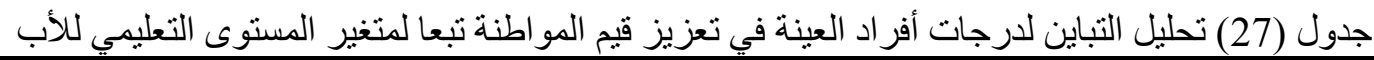

\begin{tabular}{|c|c|c|c|c|c|}
\hline الدلالة الد & قيمة (ف) & الحرية & متوسط المربعات & مجموع المربعات & المستوى التعليمي \\
\hline \multirow{2}{*}{0.01 دال } & \multirow{2}{*}{47.925} & 2 & 2745.977 & $\begin{array}{l}5491.954 \\
\end{array}$ & بين المجموعات \\
\hline & & 137 & 57.297 & 7849.741 & داخل المجمو عات \\
\hline & & 139 & & 13341.695 & المجموع \\
\hline
\end{tabular}

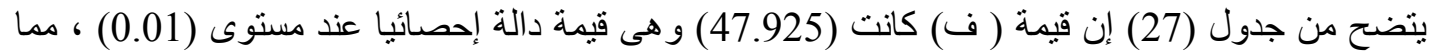

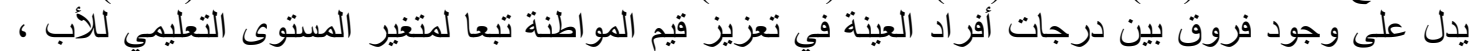

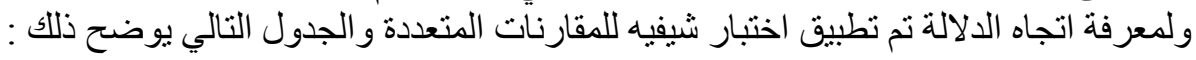
جدول (28) اختبار شيفيه للمقارنات المتعددة

\begin{tabular}{|c|c|c|c|}
\hline $\begin{array}{c}\text { م = عالي } 47.723 \\
47\end{array}$ & م = متوسط 39.946 م & م = منخفض 28.082 & المستوى التعليمي للأب \\
\hline & & - & منخفض \\
\hline & - & $* * 11.864$ & متوسط \\
\hline - & $* * 7.777$ & $* * 19.641$ & عالي \\
\hline
\end{tabular}

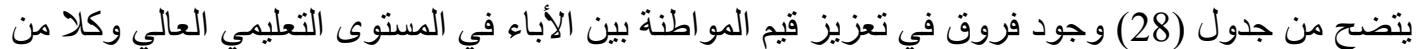

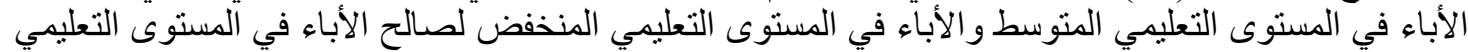

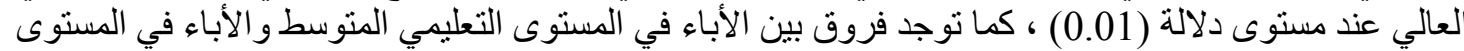

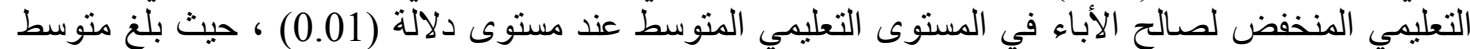

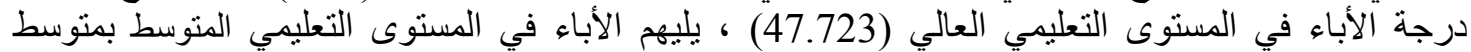

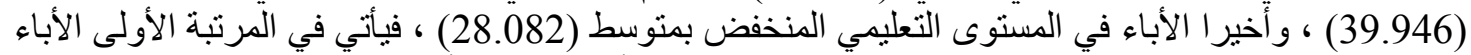

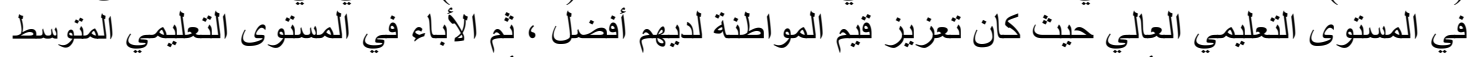

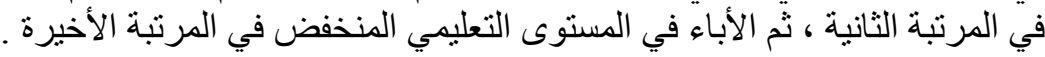


المجلة الحولية اللملور الآسسانية والإمتماعية International Journal of Humanities and Social Sciences website:www.ijohss.com Email:editor@ijohss.com ISSN: $2415-4822$

$\begin{array}{ll}\text { العدد (12) (12) April } 2020 & \end{array}$

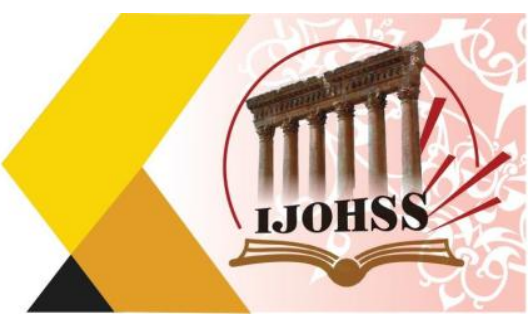

جدول (29) تحليل التباين لدرجات أفر اد العينة في تعزيز قيم المو اطنة تبعا لمتغير المستوى التعليمي للأم

\begin{tabular}{|c|c|c|c|c|c|}
\hline الدلالة الد & قيمة ( ف) & دالحرية & متوسط المربعات & مجموع المربعات & المستوى التعليمي للأم \\
\hline \multirow{2}{*}{0.0101} & \multirow{2}{*}{39.711} & 2 & 2690.029 & 5380.058 & بين المجمو عات \\
\hline & & 137 & 67.741 & 9280.502 & داخل المجمو عات \\
\hline & & 139 & & 14660.560 & المجموع \\
\hline
\end{tabular}

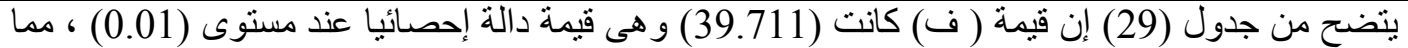

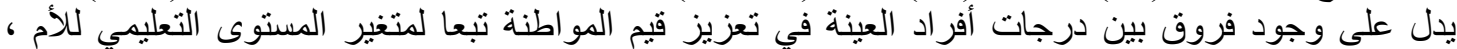

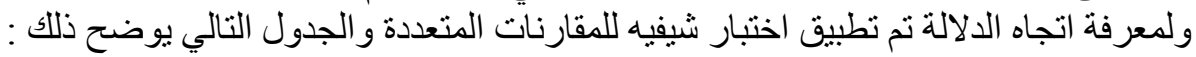
جدول (30) اختبار شيفيه للمقارنات المتعددة

\begin{tabular}{|c|c|c|c|}
\hline م = عالي 45.552 & م =منوسط 34.362 & م = منخفض 32.109 & المستوى التعليمي للأم \\
\hline & & - & منخفض \\
\hline & - & $* 2.253$ & متوسط \\
\hline - & $* * 11.190$ & $* * 13.443$ & عالي \\
\hline
\end{tabular}

يتضح من جدول (30) وجود فروق في تعزيز قيم المواطنة بين الأمهات في المستوى التعليمي العالي وكلا

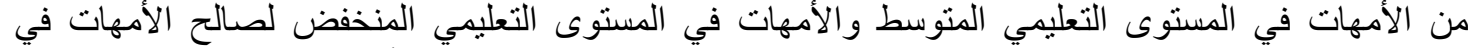

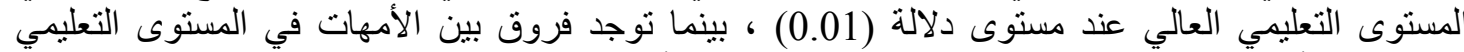

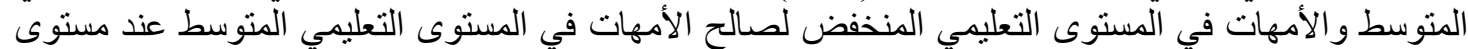

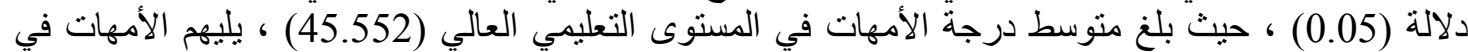

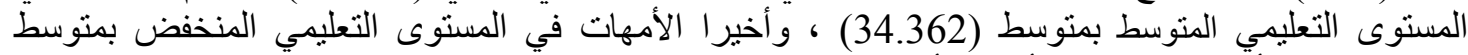

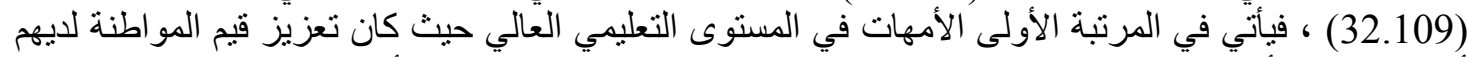

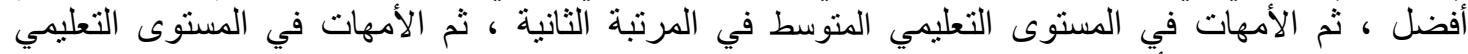
المنخفض في المرتبة الأخيرة .

جدول (31) تحليل التباين لدرجات أفر اد العينة في تعزيز قيم المواطنة تبعا لمتغير وظيفة الأب

\begin{tabular}{|c|c|c|c|c|c|}
\hline 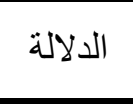 & قيمة (ف) & الحرية & متوسط المربعات & مجموع المربعات & وظيفة الأب \\
\hline \multirow{2}{*}{ 0 0.01 دال } & \multirow{2}{*}{52.313} & 2 & 2770.960 & 5541.920 & بين المجمو عات \\
\hline & & 137 & 52.969 & 7256.738 & داخل المجمو عات \\
\hline & & 139 & & 12798.658 & المجموع \\
\hline
\end{tabular}

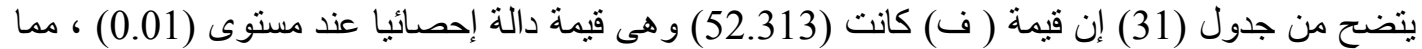

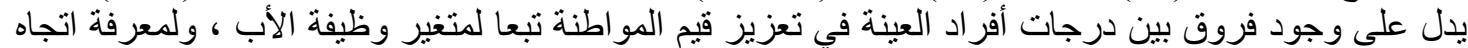

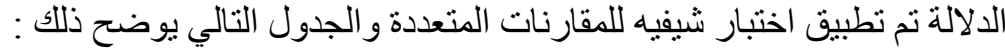
جدول (32) اختبار شيفيه للمقارنات المتعددة

\begin{tabular}{|c|c|c|c|}
\hline م = أعمال حرة 30.306 مر & ق =طاع خاص & وظعيفة حكومية & وظيفة الأب \\
\hline & & - & وظيفة حكومية \\
\hline & - & $* * 9.146$ & قطاع خاص \\
\hline - & **13.869 & $* * 23.015$ & أعمال حرة \\
\hline
\end{tabular}



International Journal of Humanities and Social Sciences website:www.ijohss.com Email:editor@ijohss.com ISSN: $2415-4822$

\section{العدد (12) ابريل 2020 Volume (12) April 2020}

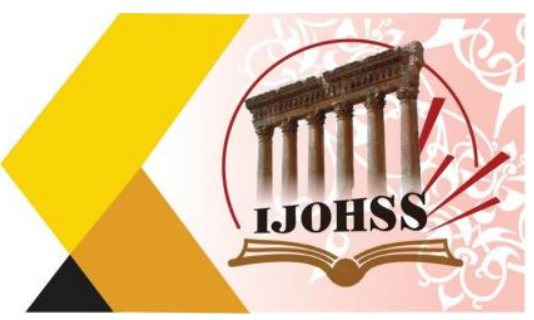

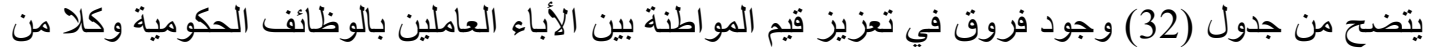

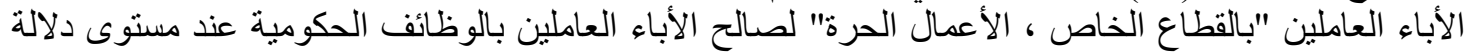

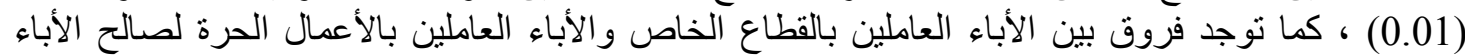

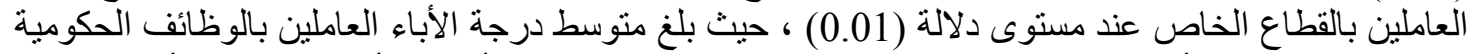

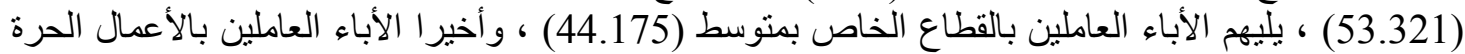

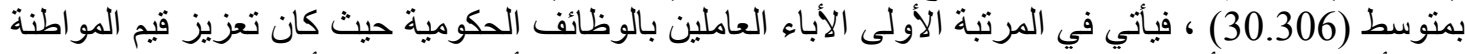
لايهم أفضل ، ثم الأباء العاملين بالقطاع الخاص في المرتبة الثانية ، ثم الأباء العاملين بالأعمال الحرة في المرئ المرتبة الأخيرة . أنهم

جدول (33) تحليل التباين لدرجات أفر اد العينة في تعزيز قيم المو اطنة تبعا لمتغير وظيفة الأم

\begin{tabular}{|c|c|c|c|c|c|}
\hline الدلالة الد & قيمة (ف) & الحرية & متوسط المربعات & مجموع المربعات & وظيفة الأم \\
\hline \multirow{3}{*}{0.0101} & \multirow{2}{*}{33.839} & 2 & 2639.867 & 5279.734 & بين المجمو عات \\
\hline & & 137 & 78.012 & 10687.690 & داخل المجمو عات \\
\hline & & 139 & & 15967.424 & المجموع \\
\hline
\end{tabular}

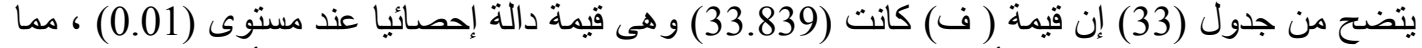

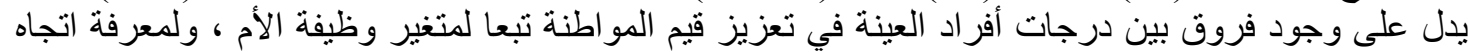

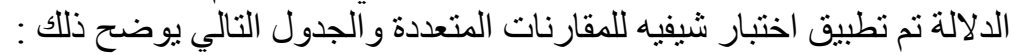
جدول (34) اختبار شيفيه للمقارنات المتعددة

\begin{tabular}{|c|c|c|c|}
\hline م = أعمال حرة 38.035 م & 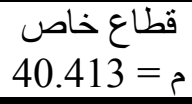 & وظيفة حكومية & وظيفة الأم \\
\hline & & - & وظيفة حكومية \\
\hline & - & $* * 11.588$ & قطاع خاص \\
\hline - & $* 2.378$ & $* * 13.966$ & أعمال حرة \\
\hline
\end{tabular}

ينضح من جدول (34) وجود فروق في تعزيز قيم المواطنة بين الأمهات العاملات بالوظائف الحكومية وكلا

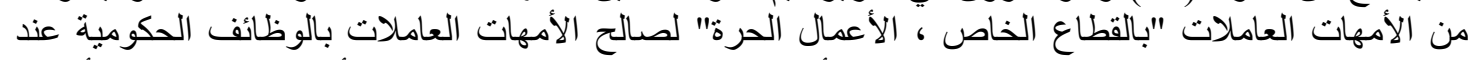

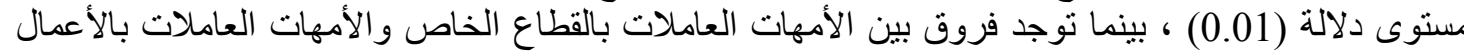

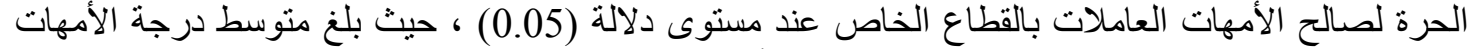

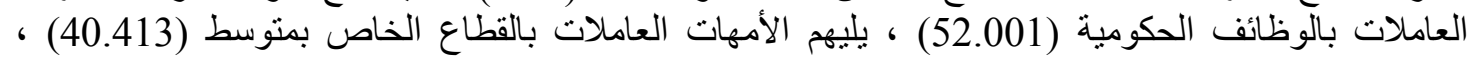

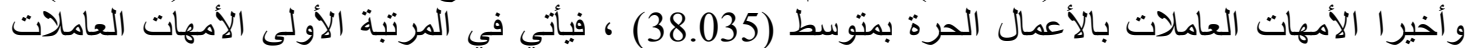

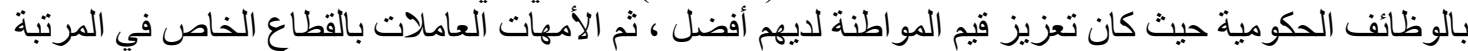

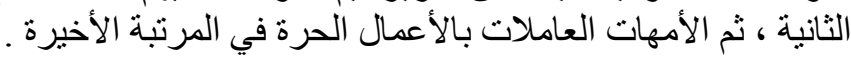

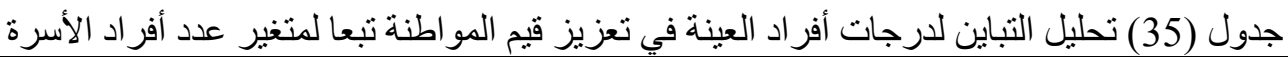

\begin{tabular}{|c|c|c|c|c|c|}
\hline الدلالة الد & قيمة (ف) & درجرية & متوسط المربعات & مجموع المربعات & عدد أفر اد الأسرة \\
\hline \multirow{2}{*}{0.010} & \multirow{2}{*}{43.615} & 2 & 2718.334 & 25436.669 & بين المجمو عات \\
\hline & & 137 & 62.326 & 8538.685 & داخل المجمو عات \\
\hline & & 139 & & 13975.354 & المجموع \\
\hline
\end{tabular}



International Journal of Humanities and Social Sciences website:www.ijohss.com Email:editor@ijohss.com ISSN: $2415-4822$

\section{العدد (12) ابريل 2020 Volume (12) April 2020}

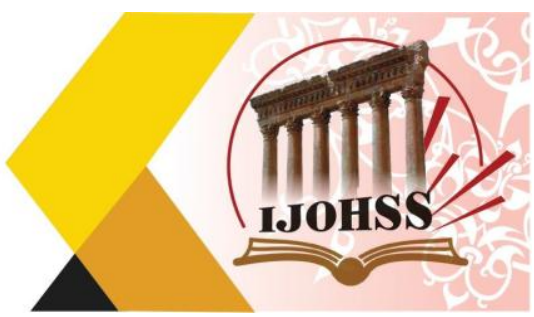

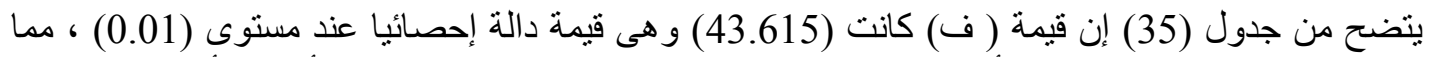

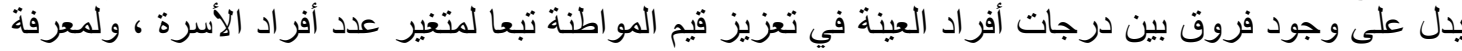

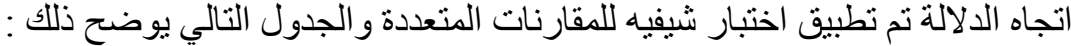
جدول (36) اختبار شيفيه للمقارنات المتعددة

\begin{tabular}{|c|c|c|c|}
\hline من 7 أفر اد فأكثر & 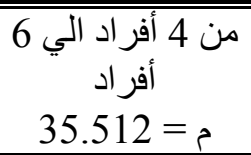 & أقل من 4 أفر اد & عدد أفر اد الأسرة \\
\hline & & - & أقل من 4 أفر اد \\
\hline & - & $* * 14.415$ & من 4 أفر اد الي 6 أفر اد \\
\hline- & $* * 13.373$ & $* * 27.788$ & من 7 أفر اد فأكثر \\
\hline
\end{tabular}

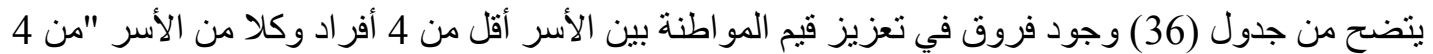

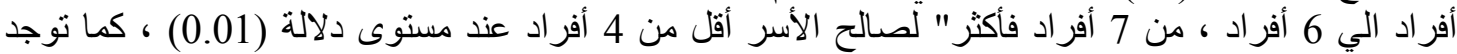

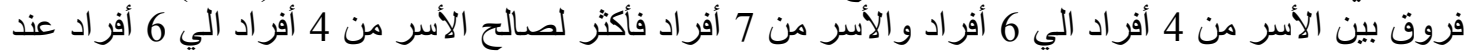

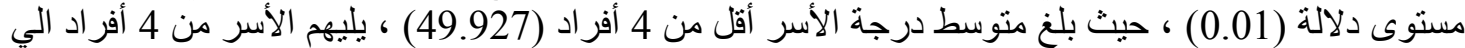

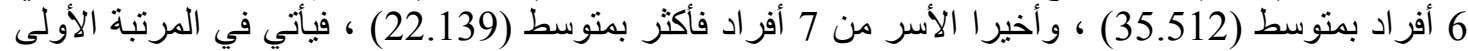
الأسر أقل من 4 أفر اد حيث كان تعزيز قيم المو اطنة لديهم أفضل ، ثم الأسر من 4 أفر أفر اد الي 6 أفر أفراد في المرنبة الثانية ، و أخير ا الأسر من 7 أفر اد فاد فأكثر .

جدول (37) تحليل التباين لدرجات أفر اد العينة في تعزيز قيم المواطنة تبعا لمتغير الدخل الثهري

\begin{tabular}{|c|c|c|c|c|c|}
\hline الدلالة الد & قيمة (ف) & الحربة & منوسط المربعات & مجموع المربعات & الدخل الثـري \\
\hline \multirow{2}{*}{0.01 دال } & \multirow{2}{*}{50.615} & 2 & 2761.628 & 5523.256 & بين المجمو عات \\
\hline & & 137 & 54.562 & 7474.981 & داخل المجمو عات \\
\hline & & 139 & & 12998.237 & المجموع \\
\hline
\end{tabular}

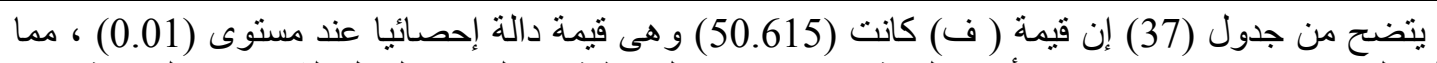

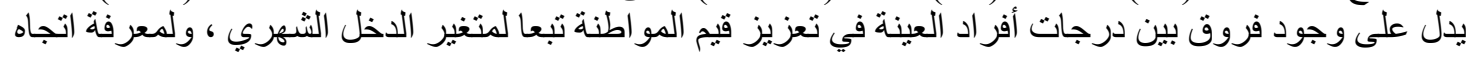

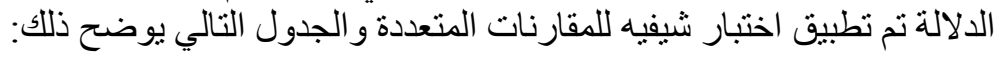
جدول (38) اختبار شيفيه للمقارنات المتعددة

\begin{tabular}{|c|c|c|c|}
\hline م= مرتفع 37.539 & م = متوسط & م = منخفض 26.140 & الدخل الثهري \\
\hline & & - & منخفض \\
\hline & - & **21.872 & متوسط \\
\hline- & $* * 10.473$ & **11.399 & مرتفع \\
\hline
\end{tabular}

يتضح من جدول (38) وجود فروق في تعزيز قيم المواطنة بين الأسر ذوي الاخل المن المنتوسط وكلا من الأسر

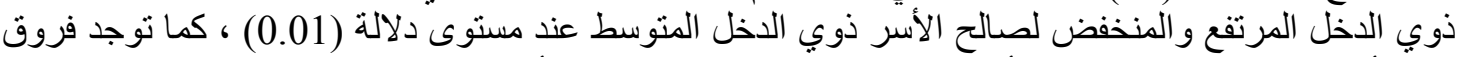

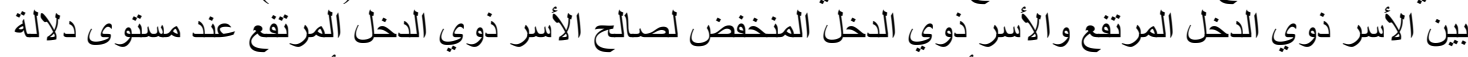

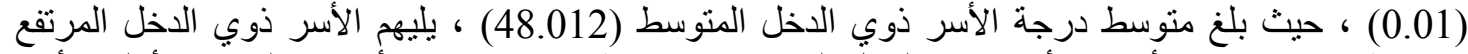

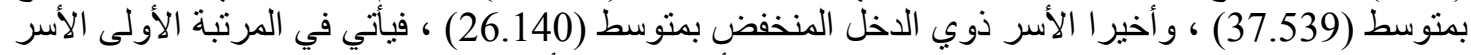
ذوي الدخل المتوسط حيث كان تعزيز قيم المواطنة لديهم أفضل ، ثم الأسر ذوي الدخل المرتفع في المرتبة الثانية الأنية

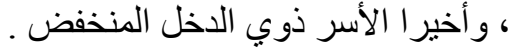



International Journal of Humanities and Social Sciences website:www.ijohss.com Email:editor@ijohss.com العدد (12) ابريل 2020 ISSN: $2415-4822$

Volume (12) April 2020

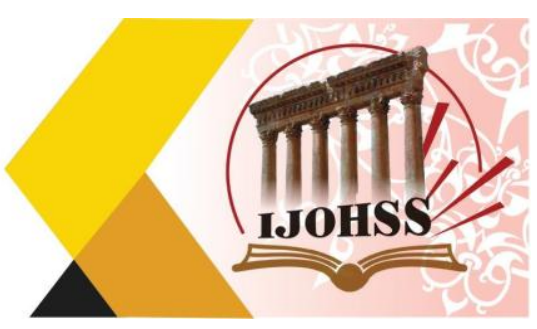

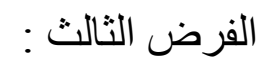

توجد علاقة ارتباطية بين استبيان أساليب المعاملة الوالدية واستبيان تعزيز قيم المواطنة

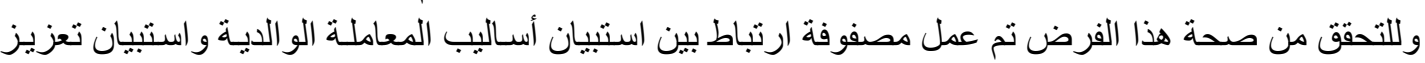

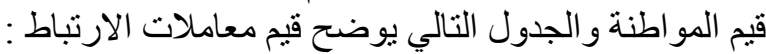
جدول (39) مصفوفة الارتباط بين استبيان أساليب المعاملة الو الدية و استبيان تعزيز قيم المو اطنة

\begin{tabular}{|c|c|c|c|c|}
\hline تعزيز قيم المو اطنة & تعزيز مفهوم المشتركة & تأعزيز مفهوم & المواطنة & \\
\hline$* * 0.792-$ & $* 0.625$ - & $* * 0.835-$ & $* * 0.914-$ & العقاب \\
\hline$* * 0.881$ & $* * 0.723$ & $* * 0.931$ & $* 0.602$ & التوجيه \\
\hline$* * 0.765$ & $* * 0.849$ & $* * 0.806$ & $* * 0.712$ & أساليب المعاملة الو الدية \\
\hline
\end{tabular}

يتضح من الجدول (39) وجود علاقة ارتباط طردي بين التوجيه و واستبيان تعزيز قيم المواطنة عند مستوى

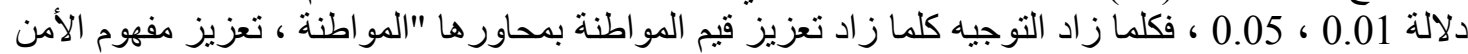

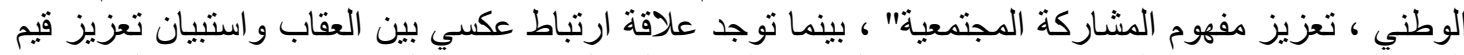

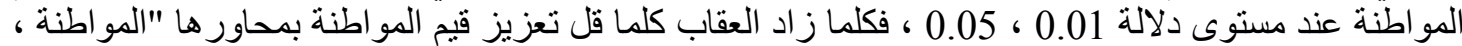

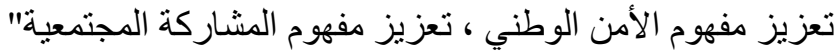

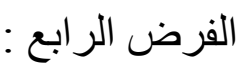

تختلف نسبة مشاركة العو امل المؤثرة علي أساليب المعاملة الو الدية

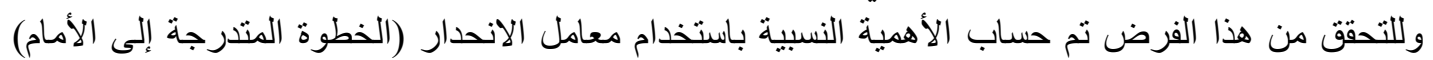

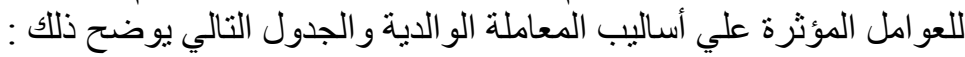

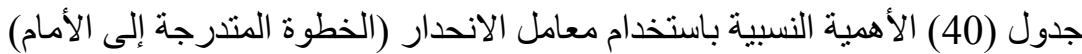
للعو امل المؤثرة علي أساليب المعاملة الو الدية النية

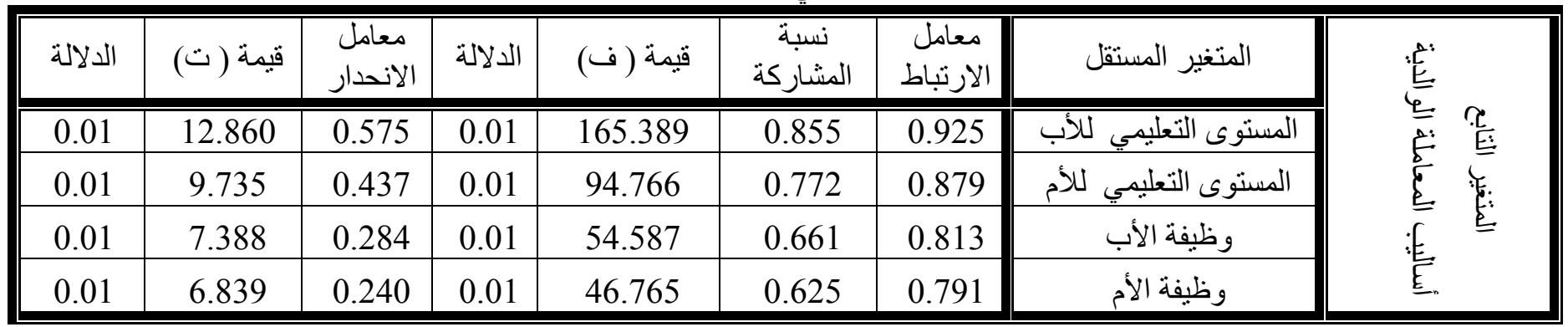

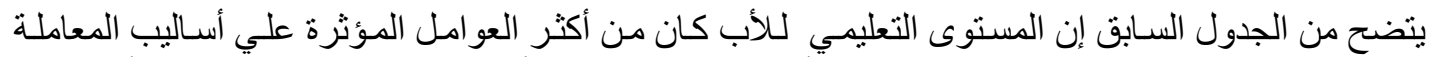

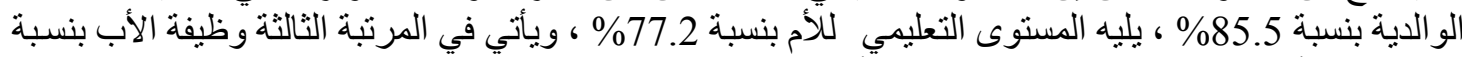

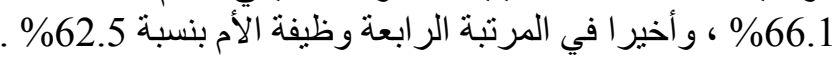

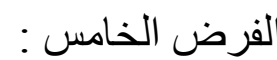
تختلف نسبة مشاركة العو امل المؤثرة علي تعزيز قيم المو اطنة

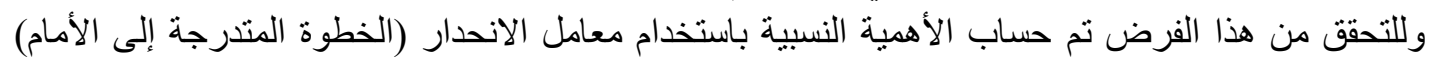

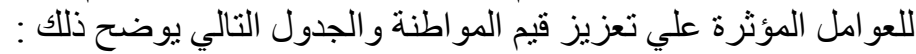




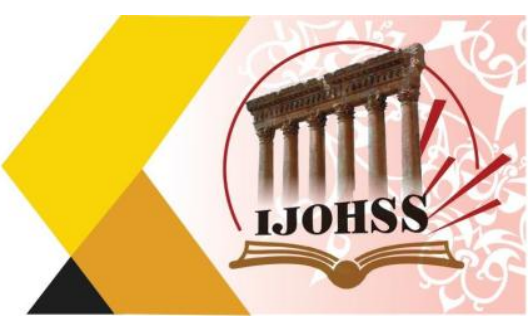

جدول (41) الأهمية النسبية باستخدام معامل الانحدار (الخطوة المتدرجة إلى الأمام) اللعو امل المؤثرة علي تعزيز قيم المو اطنة

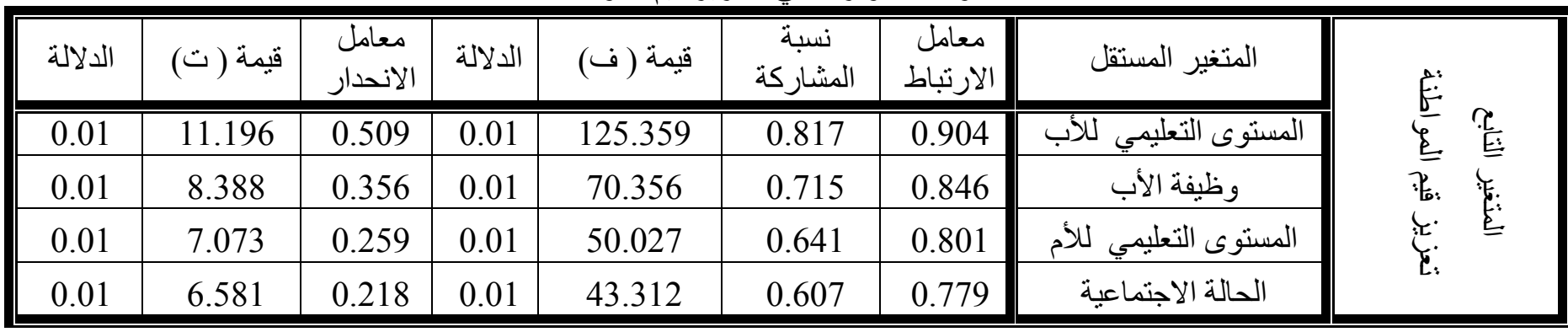

ينضح من الجدول السابق إن المستوى التعليمي للأب كان من أكثر العو امل المؤثرة علي تعزيز قيم المواطنة

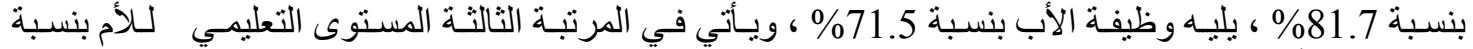
64.1\% ، و أخيرا في المرتبة الر ابعة الحالة الاجتماعية بنسبة 60.7\% \% توصيات البحث: 1- التوعية الأسرية بأهمية أساليب المعاملة الوالدية الايجابية ، وتوفير البيئة الملائمة لما لها من أثر كبير فى تعزيز قيم المو اطنة . 2- تطويز فيم المرناهج وتضمين المفاهيم والمهارات المختلفة عن تعزيز قيم المواطنة بما يتناسب مع متغيرات

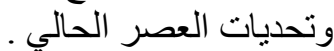
3- عقد ندوات تثقيفية عن أهمية إتباع الأساليب الإيجابية في التعامل مع الأبناء و التي تنعكس بدور ها عليهم .

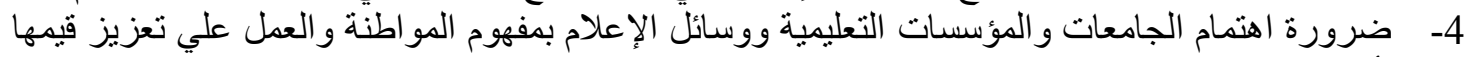

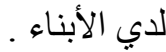
5- تنفيذ دور الات تدريبية بهدف تعزيز قيم المو اطنة للأبناء حيث أنهم المستقبل و المسئولين عن تتمية المجنمع .

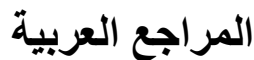

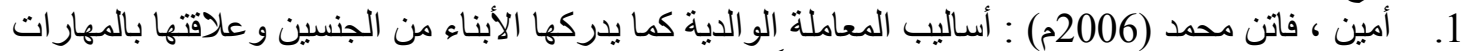

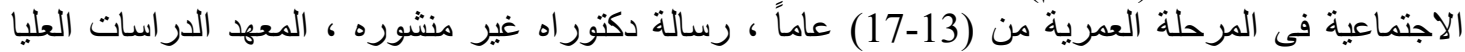

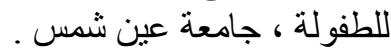
2.

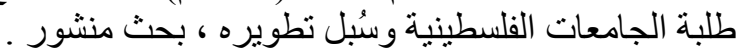
3.

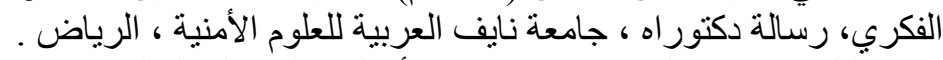

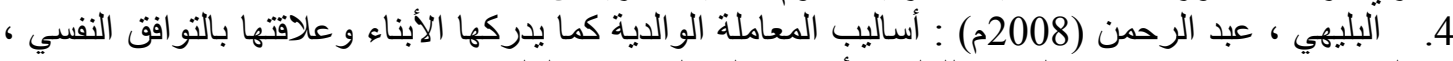

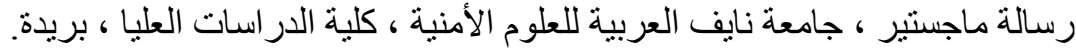

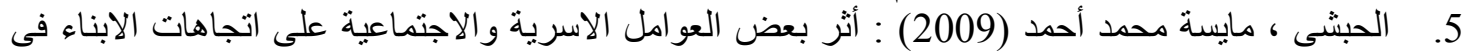
المرحلة الجامعية نحو عمل الام ، مجلة بحوث الاقتصاد المنزلى المبلى ، جامعة المنوفية.

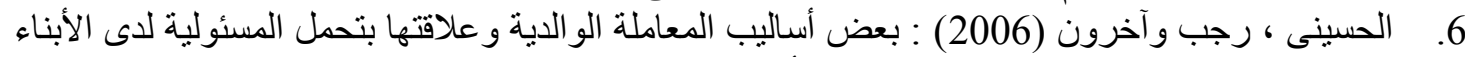

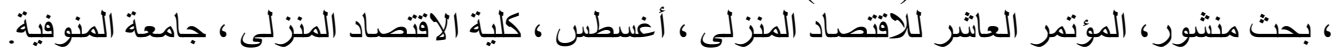
7.

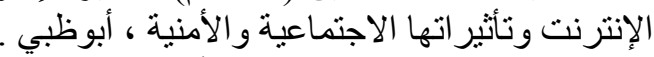

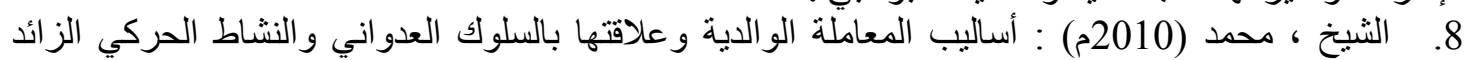

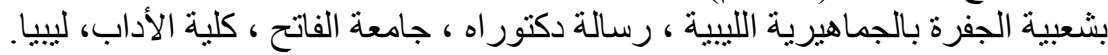

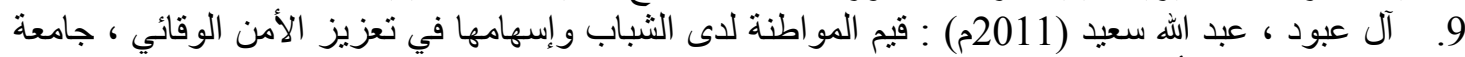

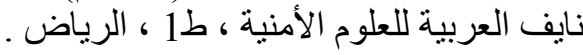




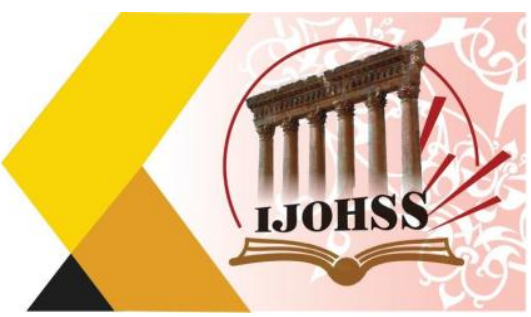

10. العمري ، سيف ناصر علي (2014م) : التربية من أجل المواطنة في دول مجلس التعاون لدول الخليج

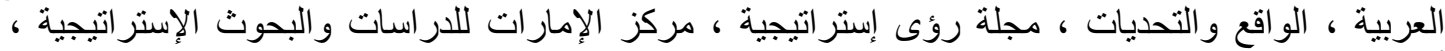

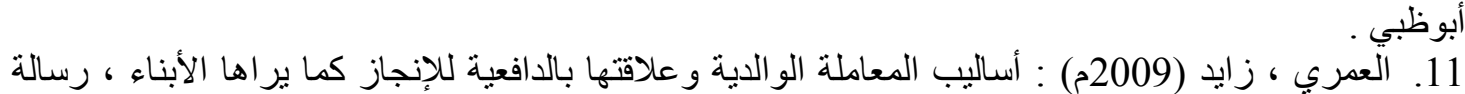

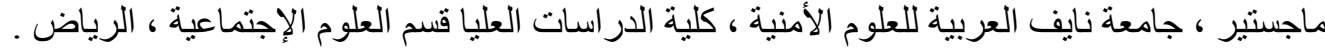

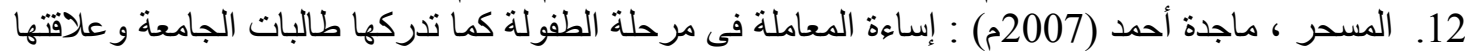
بأعر اض الاكتئاب ، رسالة ماجستير ، جامعة الماند الملك سعود ، المملكة العربية السعودية.

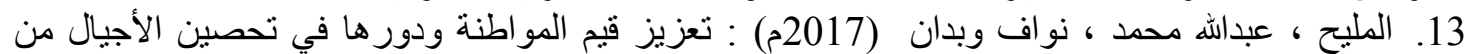

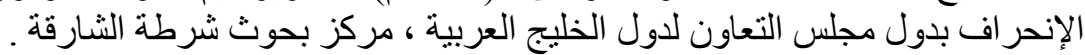

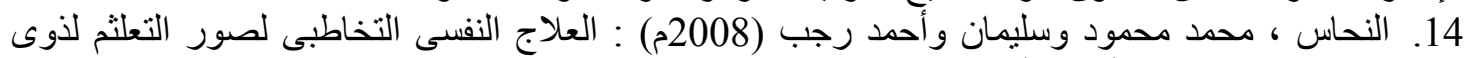
صعوبات التعلم ، جمعية أولياء أمور المعاقين / الجمعية الخليجية للاعاقة ، الملتقى الثامن للجمعية الخليجية للاعاقة .

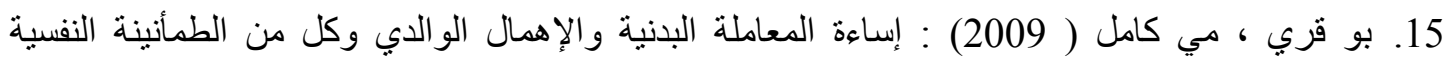

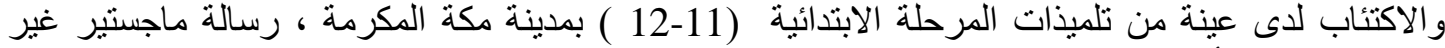

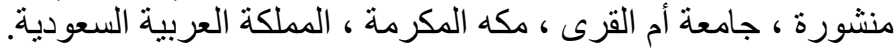

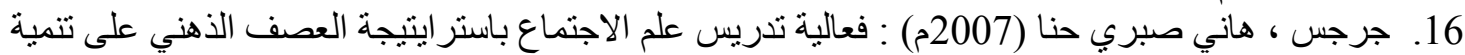

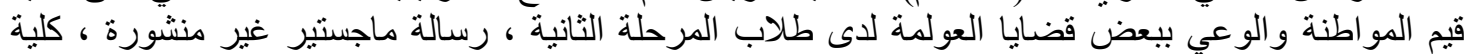

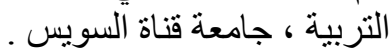

17. حقى ، زينب محمد ، أبو سكينة ، نادية حسن (2009) : العلاقات الاسرية بين النظرية والتطبيق ، مكتبة عين شمس ، القاهرة.

18. حمدان ، سعيد بن سعيد (2004) : أهمية الاسرة كمؤسسة اجتماعية ، ورقة عمل مقدمة لندوة المجتمع والأمن المنعقدة بكلية الملك فهذ ، الرئ الرياض.

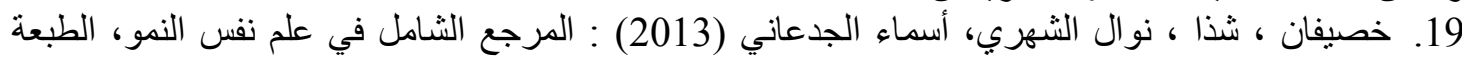
الأولى ، خوارزم العلمية ، جدة.

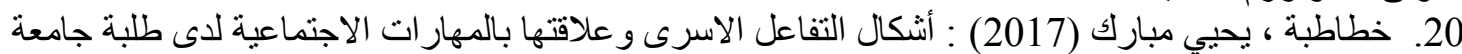

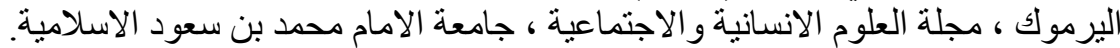

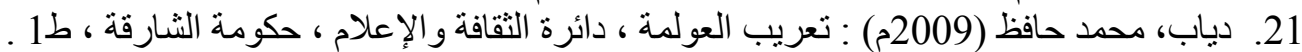

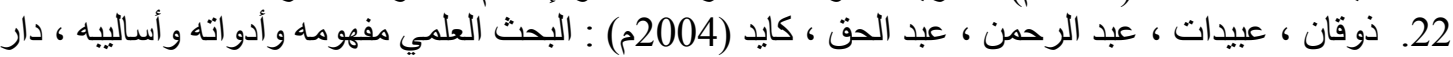

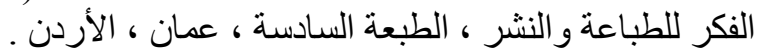

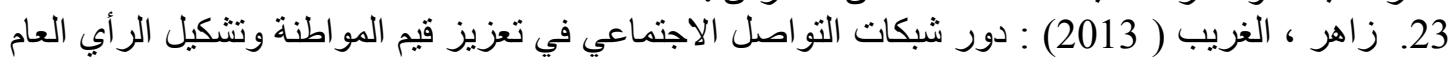

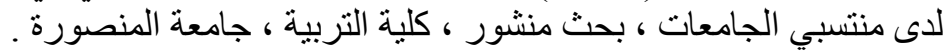
24. زمزم ، علي عيسى (2015م) : مهدّدات قيم المواطنة و علاقتها بالانحر اف السلوكي ، مركز بحوث شرطة

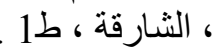
25. شريف ، أمين فرج (2012م) : المواطنة ودور ها في تكامل المجتمعات التعددية ، دار الكتب القانونبة ، القاهرة . 26. شُعيبي ،إنعام (2009م) : أساليب المعاملة الو الدية وعلاقتها بإتخاذ الأبناء لقرار اتهم في المرحلة الثانوية ، رسالة ماجستير ، جامعة أم القرى ، مكة المعام المكرمة.

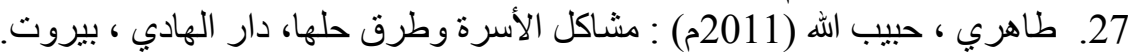

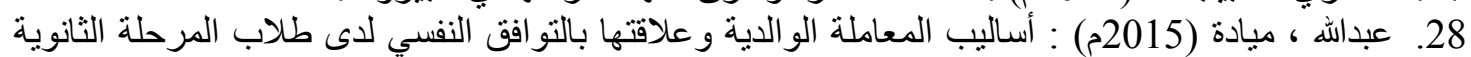

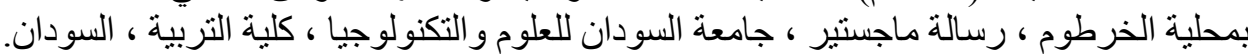

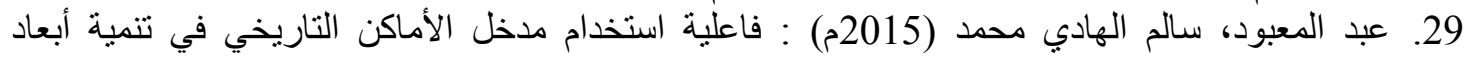

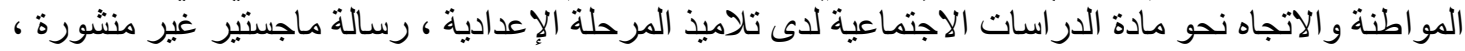
كلية التربية ، جامعة بنها 


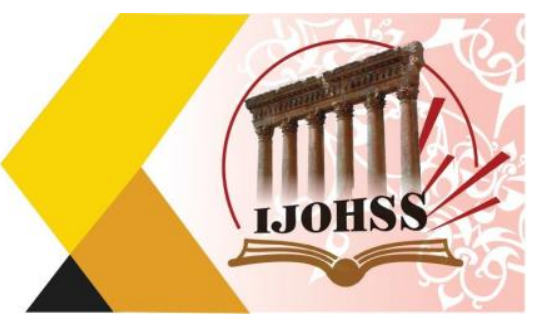

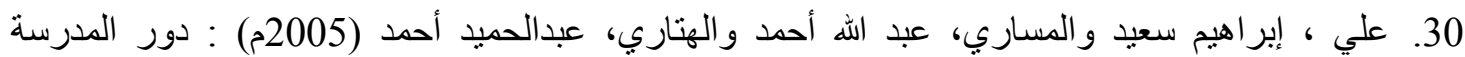

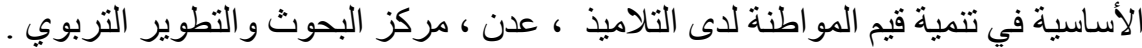

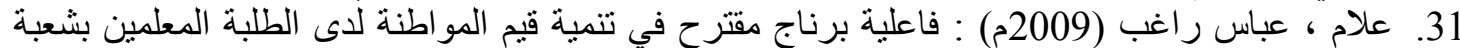
الدراسات الاجتماعية بكلية التربية ، المؤتمر العلمي الثاني "مدرسة المستقبل : الواقع و والمأمول" ، كلية التربية التربية

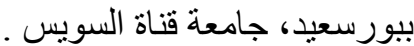

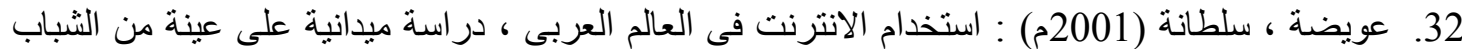

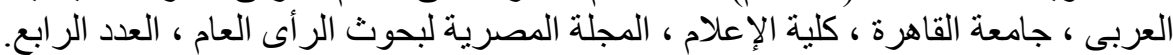

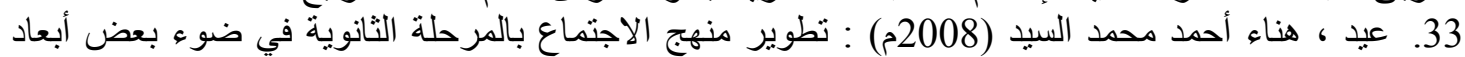

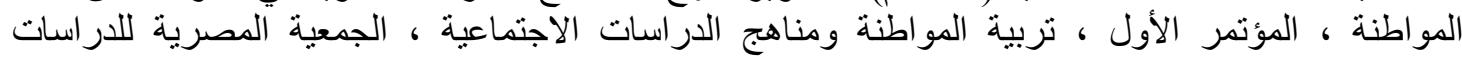

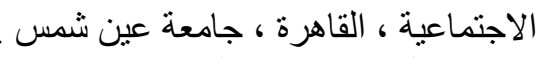

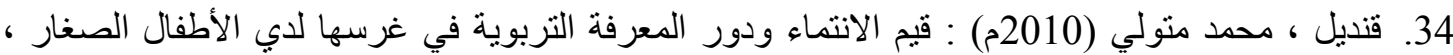

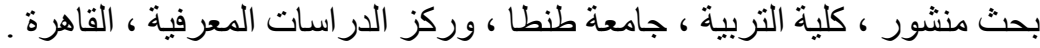

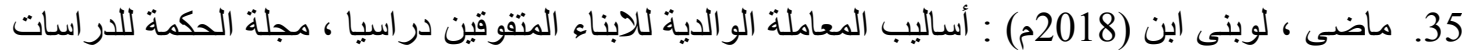

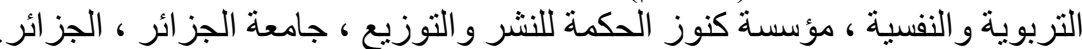

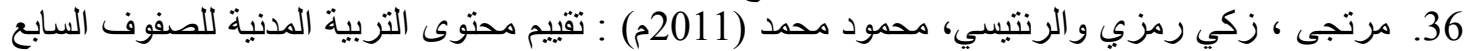

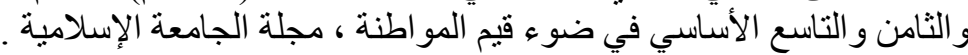

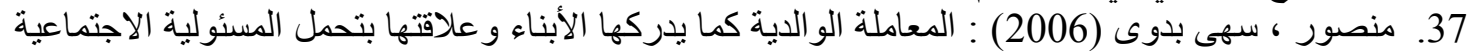

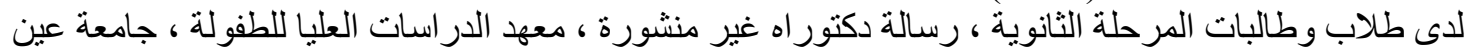

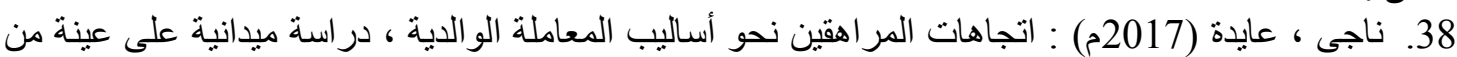

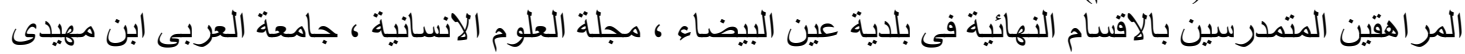

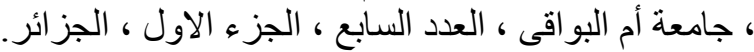

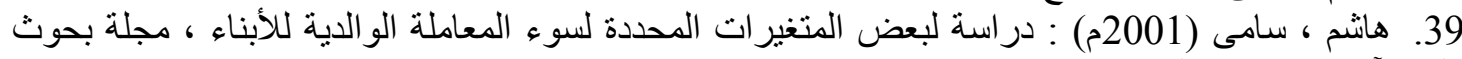

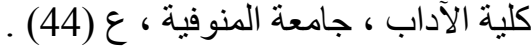



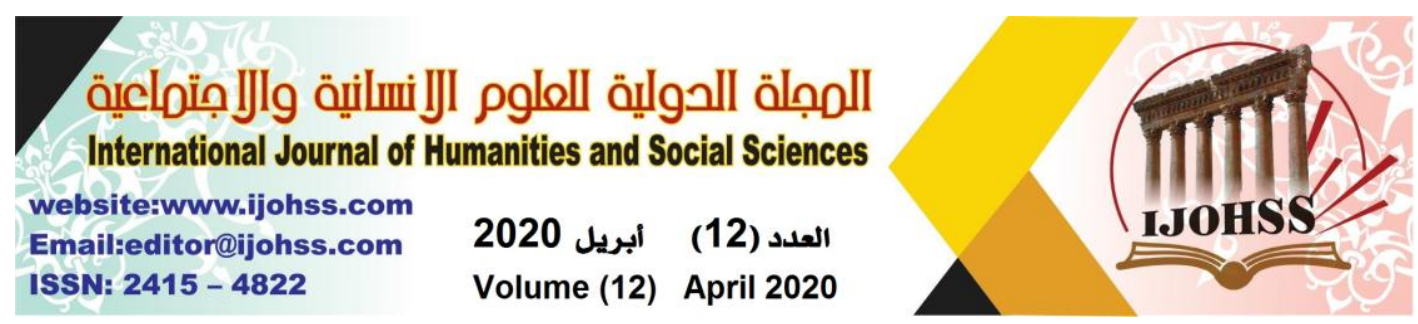

\section{References}

1- Amin, Faten Muhammad (2006 AD): Parenting methods as perceived by children of both sexes and their relationship to social skills in the age group (13-17 years), unpublished $\mathrm{PhD}$ thesis, Institute of Higher Studies for Childhood, Ain Shams University. 2- Al-Agha, Amira, Islam, Nour (2017): The role of social media in promoting social values among Palestinian university students and ways to develop it, published research.

3- Al-Baqmi, Faisal Bin Ayed (2010 AD): The nature of the relationship between parents and children and its role in preventing intellectual deviation, $\mathrm{PhD}$ thesis, Naif Arab University for Security Sciences, Riyadh.

4- Al-Balaihi, Abdul-Rahman (2008 AD): Parental treatment methods as perceived by children and their relationship to psychological compatibility, MA, Naif Arab University for Security Sciences, College of Graduate Studies, Buraidah.

5- Al-Habashi, Maysa Muhammad Ahmad (2009): The effect of some family and social factors on the attitudes of children in the university stage towards the work of the mother, Journal of Home Economics Research, Menoufia University.

6- Al-Husseini, Rajab et al. (2006): Some methods of parental treatment and its relationship to taking responsibility with children, published research, the tenth conference of home economics, August, Faculty of Home Economics, Menoufia University.

7- Al-Khayyat, Ahmed Hussein (2006): The impact of the Internet on the educational process, a working paper presented to the Symposium of Internet Networks and its social and security implications, Abu Dhabi

8- Sheikh, Muhammad (2010 AD): Parental treatment methods and their relationship to aggressive behavior and excessive motor activity in the popularity of Al-Jafra in the Libyan Jamahiriya, Ph.D. thesis, Al-Fateh University, College of Arts, Libya.

9- Al-Abboud, Abdullah Saeed (2011 AD): The values of citizenship among youth and their contribution to strengthening preventive security, Naif Arab University for Security Sciences, 1st ed., Riyadh.

10- Al-Omari, Saif Nasser Ali (2014): Education for Citizenship in the Gulf Cooperation Council States, Reality and Challenges, Strategic Insights Magazine, Emirates Center for Strategic Studies and Research, Abu Dhabi.

11- Al-Omari, Zayed (2009): Parental treatment methods and their relationship to motivation for achievement as seen by children, MA, Naif Arab University for Security Sciences, College of Graduate Studies, Department of Social Sciences, Riyadh.

12- Al-Mashar, Magda Ahmed (2007 AD): Childhood abuse as perceived by university students and its relationship to symptoms of depression, Master Thesis, King Saud University, Saudi Arabia.

13- Al-Maleh, Abdullah Mohammed, Nawaf and Badan (2017): Enhancing the values of citizenship and its role in protecting generations from delinquency in the Gulf Cooperation Council states, Sharjah Police Research Center.

14- Al-Nahhas, Muhammad Mahmoud, Suleiman and Ahmed Ragab (2008 AD): Phonetic Psychotherapy for Pictures of Stuttering for People with Learning Disabilities, Handicapped Guardians Association / The Gulf Disability Society, the eighth meeting of the Gulf Disability Society.

15- Bou Quri, Mai Kamel (2009): Physical abuse, parental neglect, and both psychological reassurance and depression among a sample of primary schoolgirls (12-11) 

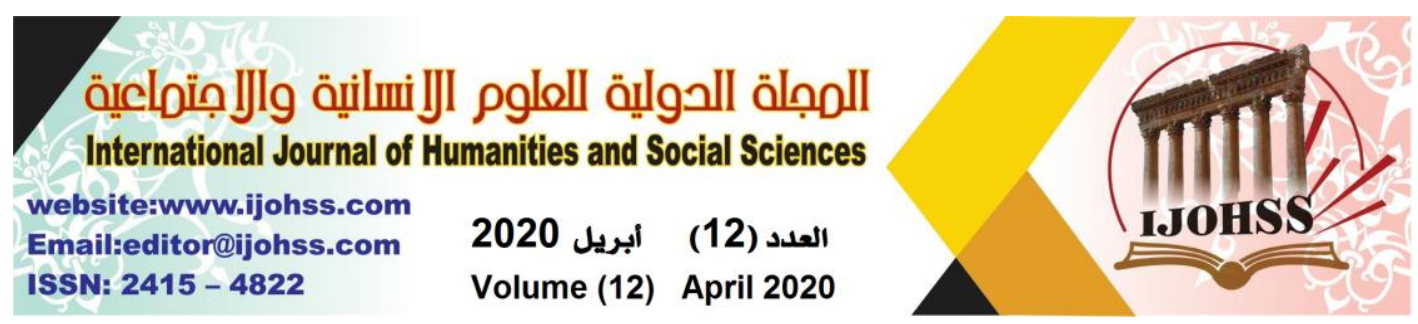

in the city of Makkah Al-Mukarramah, unpublished Master Thesis, Umm Al-Qura University, Makkah Al-Mukarramah, Kingdom of Saudi Arabia.

16- Gerges, Hani Sabry Hanna (2007 AD): The effectiveness of teaching sociology with the result of brainstorming on developing the values of citizenship and awareness of some issues of globalization among students of the second stage, unpublished Master Thesis, Faculty of Education, Suez Canal University.

17- Haqqi, Zainab Muhammad, Abu Sukaina, Nadia Hassan (2009): Family Relationships between Theory and Practice, Ain Shams Library, Cairo.

18- Hamdan, Saeed bin Saeed (2004): The importance of the family as a social institution, a working paper presented to the community and security symposium held at King Fahd College, Riyadh.

19- Khasifan, Shaza, Nawal Al-Shehri, Asmaa Al-Jadaani (2013): The Comprehensive Reference on Growth Psychology, First Edition, Khwarizm Scientific, Jeddah.

20- Khatatba, Yahya Mubarak (2017): Forms of family interaction and its relationship to social skills among Yarmouk University students, Journal of Humanities and Social Sciences, Imam Muhammad bin Saud Islamic University.

21- Diab, Mohamed Hafez (2009): Arabization of Globalization, Department of Culture and Information, Sharjah Government, 1st edition.

22- Touqan, Obaidat, Abd al-Rahman, Abd al-Haqq, Kayed (2004): Scientific Research, Its Concept, Tools, and Methods, Dar Al-Fikr for Printing and Publishing, Sixth Edition, Amman, Jordan.

23- Zahir, Al-Ghareeb (2013): The role of social networks in promoting the values of citizenship and shaping public opinion among university employees, published research, college of education, Mansoura University.

24- Zamzam, Ali Issa (2015 CE): Threats to the values of citizenship and its relationship to behavioral deviation, Police Research Center, Sharjah, 1st edition.

25- Sherif, Amin Faraj (2012): Citizenship and its role in the integration of pluralistic societies, Dar Al Kutub Al-Qanuni, Cairo.

26- Shuaibi, Inaam (2009): Parental treatment methods and their relationship to children's decision-making at the secondary level, MA, Umm Al-Qura University, Makkah AlMukarramah.

27- Taheri, Habibullah (2011): Family problems and ways to solve them, Dar Al-Hadi, Beirut.

28- Abdullah, Mayada (2015 AD): Parental treatment methods and their relationship to psychological compatibility among high school students in Khartoum locality, Master Thesis, Sudan University of Science and Technology, College of Education, Sudan.

29- Abdel-Maaboud, Salem Al-Hadi Mohammed (2015 AD): The effectiveness of using the historical places entrance in developing the dimensions of citizenship and the trend towards social studies subject for prep students, unpublished Master Thesis, College of Education, Benha University

30- Ali, Ibrahim Saeed and Al-Masary, Abdullah Ahmad Al-Hattari, Abdul Hamid Ahmed (2005): The role of the primary school in developing the values of citizenship among students, Aden, Center for Educational Research and Development.

31- Allam, Abbas Ragheb (2009): The effectiveness of a proposed program in developing the values of citizenship among teachers of students in the Social Studies Division of the 

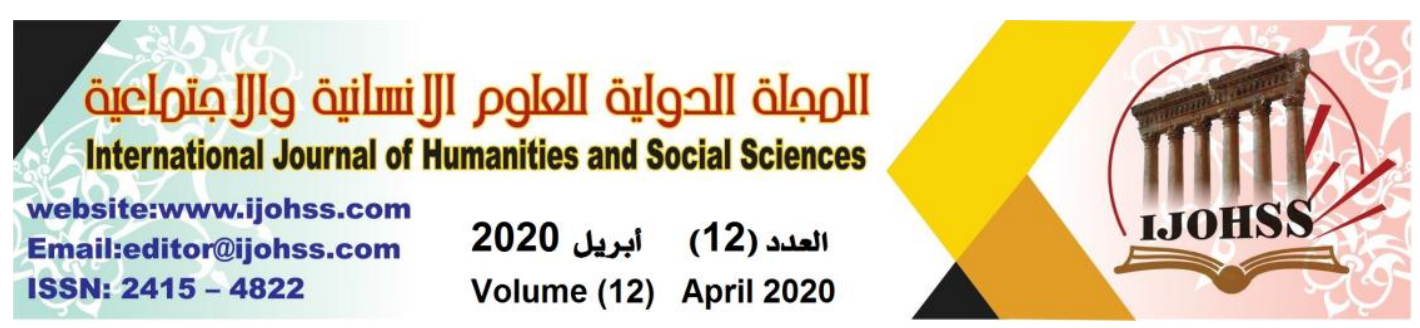

Faculty of Education, the second scientific conference "School of the Future: Reality and Expectation", Faculty of Education in Port Said, Suez Canal University.

32- Awaida, Sultana (2001 AD): Using the Internet in the Arab world, a field study on a sample of Arab youth, Cairo University, Faculty of Information, the Egyptian Journal of Public Opinion Research, fourth edition.

33- Eid, Hanaa Ahmed Mohamed El-Sayed (2008 AD): developing the curriculum for the secondary stage in the light of some dimensions of citizenship, the first conference, citizenship education and curricula for social studies, Egyptian Society for Social Studies, Cairo, Ain Shams University.

34- Qandil, Mohamed Metwally (2010 AD): Values of belonging and the role of educational knowledge in its implantation in young children, published research, faculty of education, Tanta University, and Center for Cognitive Studies, Cairo.

35- Madi, Lubna Ibn (2018 AD): Parental treatment methods for children excelling in studies, Al-Hikma Journal for Educational and Psychological Studies, Konouz Al-Hikma Foundation for Publishing and Distribution, University of Algeria, Algeria.

36- Murtaja, Zaki Ramzi and Al-Rantisi, Mahmoud Mohamed (2011 AD): Evaluation of the content of civic education for the seventh, eighth, and ninth grades in light of the values of citizenship, Islamic University Journal.

37- Mansour, Suha Badawi (2006): Parental treatment as perceived by children and its relationship to assume social responsibility among high school students and students, unpublished doctoral thesis, Institute of Higher Studies for Childhood, Ain Shams University.

38- Nagy, Aida (2017): Adolescents' attitudes toward parental treatment methods, a field study on a sample of adolescents studying in the final departments in the municipality of Ain al-Bayda, Journal of Humanities, University of Arab Ibn Ibn Mahidi, University of Umm al-Bawaki, number seven, first part, Algeria.

39- Hashem, Sami (2001): a study of some of the specific variables of parental abuse of children, Journal of Research, Faculty of Arts, Menoufia University, p (44).

40- Powell, D.R. (2006): Families and early childhood interventions. In W . Damon \& lerner (Eds.), Hardbook of child psychology ( 6th ed.) New York: wiley.

41- Gerie, R. D. \& Dana, N.(2002).Family interactions and Child Psychopathology Child Development, New Orleans .

42- Liber Juliette.M، 2004، Sibling Comparison of Differential Parental Treatment in Adolescence: Gender, Self-Esteem, and Emotionality as Mediators of the ParentingAdjustment Association، University Park، United States of America 